\title{
Repositioning Therapeutics for COVID-19: Virtual Screening of the Potent Synthetic and Natural Compounds as SARS-CoV-2 3CLpro Inhibitors
}

\author{
Ahmad Sattari \\ University of Zanjan \\ Ali Ramazani ( $\square$ aliramazani@gmail.com ) \\ University of Zanjan \\ Hamideh Aghahosseini \\ University of Zanjan
}

\section{Research Article}

Keywords: COVID-19, Drug discovery, Medicinal chemistry, Molecular docking, Synthetic and natural ligands

Posted Date: June 30th, 2020

DOl: https://doi.org/10.21203/rs.3.rs-37994/v1

License: (9) This work is licensed under a Creative Commons Attribution 4.0 International License. Read Full License

Version of Record: A version of this preprint was published at Journal of the Iranian Chemical Society on March 26th, 2021. See the published version at https://doi.org/10.1007/s13738-021-02235-7. 


\section{Abstract}

Today, finding potential therapeutics for COVID-19 caused by the widespread transmission of SARS-CoV-2 has become a global challenge. Molecular docking investigation of the therapeutic potential of marketed drugs is a fast and cost effective approach to provide a solution to this problem. In this study, docking simulations performed on the reported structure of the virus main protease, $3 C L$ pro, to identify potential inhibitors. Accordingly, a database of 50 synthetic compounds including approved drugs and those undergoing clinical trials, and 40 natural compounds particularly those employed in traditional Iranian medicine was constructed. The results indicated that the anti-inflammatory drugs, Licofelone acyl glucuronide and delta-bilirubin, and natural compounds such as kappa-carrageenan conformer and beta$D$-galactopyranosy/ with minimal side-effects, according to in-vitro studies, are good candidates to block the enzymatic activity of SARS-CoV-2 3CLpro. Moreover, the compound 1 could be a potential drug candidate for COVID-19 due to its favorable interactions with the 3CLpro.

\section{Introduction}

Coronaviruses are enveloped, positive-sense, single-stranded RNA viruses, which in humans range from the mild respiratory tract infections such as common cold to lethal infections such as Middle East respiratory syndrome coronavirus (MERS-CoV), severe acute respiratory syndrome coronavirus (SARS$\mathrm{CoV}$ ) and severe acute respiratory syndrome coronavirus 2 (SARS-CoV-2). The first discovery of human coronaviruses back to the late $1960 \mathrm{~s}^{[1]}$. The viral spike peplomers created a crown-like morphology on the surface of the virus, which is the basis for naming the coronaviruses ${ }^{[2]}$. Coronaviruses particles have enveloped and pleomorphic structure ${ }^{[3]}$ with the diameter of around $120 \mathrm{~nm}{ }^{[4]}$ and a distinct pair of electron dense shells formed their envelope ${ }^{[5]}$. The coronaviruses are protected outside the host cells by their lipid bilayer envelope and nucleocapsids inside them, as well as membrane proteins ${ }^{[6]}$. The coronaviruses subfamily is divided into the four genera called alpha-, , beta-, gamma- and deltacoronavirus [7]. The SARS-CoV-2 belongs to the genus Beta-coronavirus from group 2B, which represented close to $79 \%$ sequence similarity to the SARS-CoV according to the next-generation sequencing technology ${ }^{[8]}$.

Considering the $96 \%$ similarity of the SARS-CoV-2 to a bat coronavirus, it also appears to have originated from bats ${ }^{[9]}$.

The rapid spread of the SARS-CoV-2 has sparked alarm worldwide. The outbreak is believed to have begun in Wuhan, China, in late December $2019^{[10]}$, although today, the epicenter of the outbreak is Europe. This pathogen was named as 2019 novel coronavirus (2019-nCoV) by the World Health Organization (WHO) ${ }^{[11]}$ and later renamed as SARS-CoV-2 by the International Committee on Taxonomy of Viruses and the causing disease named as coronavirus disease 2019 (COVID-19) ${ }^{[12]}$. The virus seems to spread from person-to-person very easily, which makes containment efforts difficult. As of April 6 , 
2020, a total of more than $1,273,990$ people have been infected by the COVID-19 and the total number of deaths reached 69,444 across the world ${ }^{[13]}$.

So far no antiviral agent has been proven for treat human coronavirus infections and preventive vaccines are still being explored. This is while, the outbreak caused massive disruptions to the nations' health and economy. Therefore, the dire need to find potential therapeutic agents is strongly felt. In this regard, many research teams have focused their researches on finding an effective way for the treatment of COVID-19 as one of the most critical issues of our time. For the first time, Zhu et al. determined whole-genome sequence of SARS-COV-2 which can help to quickly detect the virus in patients ${ }^{[14]}$. Then several laboratories have been submitted this whole-genome sequences to global initiative on sharing all influenza data ${ }^{[15]}$. Four major structural proteins have been encoded in coronaviruses: Spike (S) protein, envelope $(E)$ protein, membrane $(M)$ protein, and nucleocapsid $(N)$ protein ${ }^{[16]}$. The study of biological structures of these proteins in SARS-CoV-2 is still at a preliminary stage and heretofore only the crystal structure of SARS-CoV-2 3CL pro (3-chymotrypsin-like proteinase, 3CLpro) was solved and released (Protein Data Bank code: 6LU7) ${ }^{[17]}$.

According to the target types, the potential anti-coronavirus therapies is subdivided into human cells- and virus-based therapeutics subdivisions. If the human cells were considered as a target, the anticoronavirus effect could be induced via blocking of the human cells signaling pathways which are essential for virus replication ${ }^{[16]}$. Moreover, the blocking of the entry receptor proteins on the surface of human cells could prevent from virus attachment to the target cells. As instances, the angiotensinconverting enzyme 2 (ACE2) was identified as a SARS-CoV receptor ${ }^{[18]}$ and the dipeptidyl peptidase-4 (DPP4) was identified as a MERS-CoV receptor ${ }^{[19]}$. If the coronavirus was considered as a target, the antivirus effect could be induced by blocking the receptor-binding domain of virus, hampering viral selfassembly process, preventing the virus RNA synthesis and inhibiting viral replication. The $3 C L$ pro has a vital role in coronaviruses replication ${ }^{[20]}$, hence, it could be a promising target to develop anti-SARS-CoV2 drugs ${ }^{[21]}$.

The beta-coronaviruses are proteolytically cleaved to various proteins employing papain-like protease (PLpro) and 3CLpro. The viral polyprotein is cleaved at eleven distinct sites by $3 C L$ pro and thereby various non-structural proteins are generated that are important for viral replication ${ }^{[20]}$.

Some potential inhibitors were identified against SARS-CoV3CLPro and MERS-CoV3CLPro according to the structure-activity analysis ${ }^{[22]}$. Given the vital role of $3 C L$ pro in the life cycle of the coronaviruses, studying this protein to find therapeutics against the SARS-CoV-2 could be very important.

Considering the rapidly spreading COVID-19 pandemic and the utmost importance of rapid access to the safe and effective medicines, molecular modeling investigation of the therapeutic potential of marketed drugs could be a fast and cost effective way to help solve this problem. 
Herein, the molecular docking studies were performed on a broad range of reported synthetic drugs and natural compounds employing AutoDock Vina program ${ }^{[23]}$, with the aim of rapid investigating their inhibition potential against SARS-CoV-2 3CLpro and ultimately repurposing them as a possible treatment for COVID-19.

In this regard, we used 3CLpro as a target to screen 90 compounds including synthetic compounds (50 compounds) with various pharmacological usage (such as antiviral, anti-inflammatory, anti-HIV, antimalarial, antibacterial, anticancer, antioxidant, etc.) and natural compounds particularly those employed in traditional Iranian medicine, with its great history of medicine and pharmacy ${ }^{[24]}$, (40 compounds) by virtual screening protocol. The prediction of the inhibition potential of these compounds against SARSCoV-2 3CLpro could allow researchers to increase the likelihood of success for compounds selected for clinical trials after validating their anti-viral effects in vitro and in vivo.

\section{Computational Analysis}

\subsection{Structures of inhibitors and targets}

The information and SDF files of different synthetic and natural Covid-19 inhibitors were achieved from PubChem and Zinc15 databases and recorded in Table 1 and 2, respectively. The 2D chemical structure of suggested inhibitors are illustrated in Figure 1 and 2 followed by ChemDraw Professional V15.0 drawing and analysis. The library converted subsequently to PDB files by using Open Babel. The PDB files state the $3 \mathrm{D}$ coordination of constituent atoms and chemical bonding. The particular programs within Open Babel enable the software to minimize the input files and select the conformer with lowest energy by systematic determination of conformations and calculation of their in vacuo free energy [25]. The structural file of target molecule (3CLpro, PDB ID: $6 L U 7^{[17]}$ ) was fetched out from RCSB PDB (www.rcsb.org/pdb) with resolution of $2.16 \AA$. It is edited by removing the hetero atoms like water and ligand molecules followed by adding polar hydrogens. From here, Auto-Dock Tools 1.5.6 (ADT) was used to do all the pre-processing steps according to the more reports ${ }^{[26]}$.

Table 1. The physical information and pharmaceutical activities of several drugs and a number of chemical compounds from different resources as $3 C L$ pro inhibitors 


\begin{tabular}{|c|c|c|c|c|c|}
\hline No & Name/ Comound Cod & $\begin{array}{l}\text { No. }^{a} \\
\text { HBD }\end{array}$ & $\begin{array}{l}\text { No.b } \\
\text { HBA }\end{array}$ & HAC & Pharmaceutical function ${ }^{c}$ \\
\hline \multirow[t]{2}{*}{1} & Compound1 & 4 & 6 & 39 & - \\
\hline & CID:134816013 & & & & \\
\hline \multirow[t]{2}{*}{2} & Licofelone acyl glucuronide & 4 & 8 & 39 & Anti-inflammatory, relevant \\
\hline & CID: 71749786 & & & & \\
\hline \multirow[t]{2}{*}{3} & Ritonavir impurity $\mathrm{H}[\mathrm{EP}]$ & 1 & 8 & 41 & - \\
\hline & CID: 66832842 & & & & \\
\hline \multirow[t]{2}{*}{4} & delta-Bilirubin & 4 & 6 & 43 & Antioxidant \\
\hline & CID:129320333 & & & & \\
\hline \multirow[t]{2}{*}{5} & Raltegravir & 3 & 9 & 32 & Anti-HIV \\
\hline & CID: 54671008 & & & & \\
\hline \multirow[t]{2}{*}{6} & Nigericin & 3 & 11 & 51 & Anti-microbial \& anti-bacterial \\
\hline & ZINC000085552063 & & & & \\
\hline \multirow[t]{2}{*}{7} & Pradimicin A & 11 & 19 & 60 & Anti-HIV \& antifungal \\
\hline & ZINC000169346835 & & & & \\
\hline \multirow[t]{2}{*}{8} & Rupintrivir & 3 & 9 & 43 & Anti-HRV \\
\hline & ZINC000003919807 & & & & \\
\hline \multirow[t]{2}{*}{9} & Lopinavir & 4 & 5 & 46 & Anti- HIV \& AIDS \\
\hline & ZINC000003951740 & & & & \\
\hline \multirow[t]{2}{*}{10} & Adenylyl-(3'-5') ribavirin & 7 & 17 & 39 & Anti- influenza A virus \\
\hline & CID: 196553 & & & & \\
\hline \multirow[t]{2}{*}{11} & Novobiocin & 5 & 11 & 44 & Anti-bacterial \\
\hline & ZINC000076945632 & & & & \\
\hline \multirow[t]{2}{*}{12} & Megazone & 0 & 7 & 37 & Anti-inflammatory \\
\hline & CID: 27624 & & & & \\
\hline \multirow[t]{2}{*}{13} & CHEMBL21082 & 4 & 9 & 44 & Anti-HRV \\
\hline & ZINC000028231984 & & & & \\
\hline \multirow[t]{2}{*}{14} & Simeprevir & 2 & 10 & 52 & Anti-HCV \\
\hline & ZINC000085540268 & & & & \\
\hline
\end{tabular}




\begin{tabular}{|c|c|c|c|c|c|}
\hline \multirow[t]{2}{*}{15} & CGP 75136 & \multirow[t]{2}{*}{5} & \multirow[t]{2}{*}{10} & \multirow[t]{2}{*}{50} & \multirow[t]{2}{*}{ Anti-HIV } \\
\hline & ZINC000004394015 & & & & \\
\hline \multirow[t]{2}{*}{16} & Amenamevir & 1 & 7 & 34 & Antiviral \\
\hline & CID: 11397521 & & & & \\
\hline \multirow[t]{2}{*}{17} & Conivaptan & 2 & 3 & 38 & Inhibitor of antidiuretic \\
\hline & CID: 151171 & & & & hormone \\
\hline \multirow[t]{2}{*}{18} & CHEMBL 140521 & 3 & 8 & 43 & Anti-HRV \\
\hline & CID: 6479024 & & & & \\
\hline \multirow[t]{2}{*}{19} & Indinavir & 4 & 7 & 45 & Anti- HIV \& AIDS \\
\hline & CID: 5362440 & & & & \\
\hline \multirow[t]{2}{*}{20} & Compound 20 & 3 & 11 & 48 & Anti-HIV \& anti- TB activity \\
\hline & CID: 134814833 & & & & \\
\hline \multirow[t]{2}{*}{21} & Oxaprozin & 1 & 4 & 22 & Anti-inflammatory \\
\hline & CID: 4614 & & & & \\
\hline \multirow[t]{2}{*}{22} & Telmisartan & 1 & 4 & 39 & Anti-hypertensives \\
\hline & CID: 65999 & & & & \\
\hline \multirow[t]{2}{*}{23} & Boceprevir & 4 & 5 & 37 & Anti-HCV \\
\hline & CID: 10324367 & & & & \\
\hline \multirow[t]{2}{*}{24} & Elvitegravir & 2 & 7 & 31 & Anti-HIV \\
\hline & CID: 5277135 & & & & \\
\hline \multirow[t]{2}{*}{25} & Telaprevir & 4 & 8 & 49 & Anti-HCV \\
\hline & CID: 3010818 & & & & \\
\hline \multirow[t]{2}{*}{26} & Saquinavir & 5 & 7 & 49 & Anti- HIV \& AIDS \\
\hline & ZINC000003914596 & & & & \\
\hline \multirow[t]{2}{*}{27} & Atazanavir & 5 & 9 & 51 & Anti-HIV \\
\hline & ZINC000003941496 & & & & \\
\hline \multirow[t]{2}{*}{28} & Maraviroc & 1 & 6 & 37 & Anti- HIV \& AIDS \\
\hline & CID: 3002977 & & & & \\
\hline 29 & Compound 29 & 1 & 10 & 46 & Anti-HIV \& anti-TB activity \\
\hline
\end{tabular}


CID: 134815433

30 CHEMBL289920

3

$943 \quad$ Anti-HRV

CID: 6477669

31 CHEMBL345023

3

$\begin{array}{lll}8 & 42 & \text { Anti-HRV }\end{array}$

CID: 6478681

32 Geneticin

10

14

$34 \quad$ Anti-bacterial

CID: 134688573

33 Ritonavir

4

9

50 Anti-HIV

CID: 392622

34 Vancomycin Mimic

7

ZINC000150553684

35 Ribavirin 5'- Triphosphate

$7 \quad 16$

16

29 Antiviral

CID: 122108

36 Oseltamivir

25

$5 \quad 22 \quad$ Anti-influenza viruses

CID: 65028

37 Phenylbutazone

$\begin{array}{lll}0 & 2 & 23\end{array}$

CID: 4781

38 Licofelone

12

27

Anti-inflammatory, antipyretic, and analgesic

CID: 133021

39 Parecoxib

1

5

26

Anti-inflammatory, antipyretic activities

CID: 119828

40 Sofosbuvir

3

11

36

Anti-HCV

CID: 45375808

41 Lopinavir free Amine

4

4

34

CID: 17755107

42 Isoxicam

$2 \quad 7$

23

Anti-inflammatory and anti-

CID: 54677972

43 (1R,2R)-2-azido-1,2-dihydro

2

7

rheumatic

oseltamivir

CID: 76968516 


\begin{tabular}{|llllll|}
44 & $\begin{array}{l}\text { Etoricoxib } \\
\text { CID: } 123619\end{array}$ & 0 & 4 & 24 & NSAID, antipyretic, analgesic \\
\hline 45 & $\begin{array}{l}\text { Fingolimod } \\
\text { CID: } 107970\end{array}$ & 3 & 3 & 22 & $\begin{array}{l}\text { Immunomodulatory drug, used to } \\
\text { treat MS }\end{array}$ \\
\hline 46 & $\begin{array}{l}\text { Chloroquine } \\
\text { CID: } 2719\end{array}$ & 1 & 3 & 22 & Anti-inflammatory, antimalarial \\
47 & $\begin{array}{l}\text { Firocoxib } \\
\text { CID: } 208910\end{array}$ & 0 & 5 & 23 & $\begin{array}{l}\text { Anti-inflammatory \& } \\
\text { antineoplastic }\end{array}$ \\
48 & $\begin{array}{l}\text { Romidepsin } \\
\text { CID: } 123135747\end{array}$ & 4 & 8 & 36 & Antineoplastic activity \\
49 & $\begin{array}{l}\text { Mesalazine } \\
\text { CID: } 4075\end{array}$ & 3 & 4 & 11 & Antiinflammatory \\
\hline 50 & $\begin{array}{l}\text { Favipiravir } \\
\text { CID: } 492405\end{array}$ & 2 & 4 & 11 & Antiviral \\
\hline
\end{tabular}
a The number of hydrogen bond donors
$\mathrm{b}$ The number of hydrogen bond acceptors
${ }^{c}$ All of the pharmaceutical function information are recorded from PubCheme except the ligands containing references which are mentioned in supplementary information.

Table 2. The physical information and pharmaceutical activities of SARS-CoV-2 inhibitors from natural sources 


\begin{tabular}{|c|c|c|c|c|c|c|}
\hline No. & $\begin{array}{l}\text { Name/ Comound } \\
\text { Cod }\end{array}$ & $\begin{array}{l}\text { No. } \\
\text { HBD }\end{array}$ & $\begin{array}{l}\text { No. } \\
\text { HBA }\end{array}$ & HAC & Pharmaceutical function ${ }^{a}$ & Source ${ }^{a}$ \\
\hline 1 & $\begin{array}{l}\text { kappa-Carrageenan } \\
\text { conformer } \\
\text { ZINC96061851 }\end{array}$ & 10 & 25 & 51 & $\begin{array}{l}\text { Antiviral activity } \\
\text { against myxoviridae, } \\
\text { and coronaviridae }\end{array}$ & Red Algae \\
\hline 2 & $\begin{array}{l}\text { beta-D- } \\
\text { Galactopyranosyl } \\
\text { CID: } 23656242\end{array}$ & 9 & 19 & 50 & Anti-inflammatory & Rosa canina \\
\hline 3 & $\begin{array}{l}\text { Calycosin 7-0- } \\
\text { glucoside } \\
\text { CID: } 5318267\end{array}$ & 5 & 10 & 32 & Antiviral & Astragalus \\
\hline 4 & $\begin{array}{l}\text { Gallic acid 3- } \\
\text { cholesteryl ester } \\
\text { CID: } 101021751\end{array}$ & 3 & 5 & 39 & Antimicrobial activity & Ficus carica \\
\hline 5 & $\begin{array}{l}\text { Spicoside A } \\
\text { CID: } 44258517\end{array}$ & 0 & 7 & 30 & Neuroprotective potency & $\begin{array}{l}\text { Cichorum } \\
\text { intybus }\end{array}$ \\
\hline 6 & $\begin{array}{l}\text { Corilagin } \\
\text { CID: } 73568\end{array}$ & 11 & 18 & 45 & $\begin{array}{l}\text { NSAID, antihypertensive } \\
\text { agent }\end{array}$ & Euphorbiaceae \\
\hline 7 & $\begin{array}{l}\text { Astragalin } \\
\text { CID: } 5282102\end{array}$ & 7 & 11 & 32 & Anti-inflammatory & Rosa canina \\
\hline 8 & $\begin{array}{l}\text { Podophyllotoxin } \\
\text { acetate } \\
\text { CID: } 164791\end{array}$ & 0 & 9 & 33 & Anticancer, antiviral & Euphorbia \\
\hline 9 & $\begin{array}{l}\text { Rhamnetin 3-0- } \\
\text { beta- } \\
\text { glucopyranoside } \\
\text { CID: } 14704554\end{array}$ & 7 & 12 & 34 & - & $\begin{array}{l}\text { Syzygium } \\
\text { aromaticum }\end{array}$ \\
\hline 10 & $\begin{array}{l}\text { Astragalus } \\
\text { polyphenol } \\
\text { CID: } 5321884\end{array}$ & 7 & 9 & 29 & $\begin{array}{l}\text { Anti-inflammatory } \\
\text { antioxidant }\end{array}$ & Astragalus \\
\hline 11 & $\begin{array}{l}\text { Geraniin } \\
\text { ZINC000169289506 }\end{array}$ & 14 & 27 & 68 & antiviral & $\begin{array}{l}\text { Nephelium } \\
\text { lappaceum }\end{array}$ \\
\hline 12 & $\begin{array}{l}\text { Gallic Acid Tribenzyl } \\
\text { Ether }\end{array}$ & 1 & 5 & 33 & Antimicrobial & Ficus carica \\
\hline
\end{tabular}


CID: 11133969

$\begin{array}{llllll}\begin{array}{l}\text { Linalool-3- } \\ \text { Rutinoside }\end{array} & 6 & 10 & 32 & \begin{array}{l}\text { Antibacterial, antifungal } \\ \text { and antiviral }\end{array} & \begin{array}{l}\text { Myrtus } \\ \text { communis }\end{array}\end{array}$

CID: 21630850

$\begin{array}{lllllll}14 & \text { Rhamnopyranoside } & 9 & 15 & 42 & \text { Inhibitor of } & \text { Cichorum } \\ \text { CID: } 21606527 & & & & \text { topoisomerase I and II } & \text { Rosa canina } \\ 15 & \begin{array}{l}\text { Catechin gallate } \\ \text { CID: } 5276454\end{array} & 7 & 10 & 32 & \text { Anti-inflammatory } & \text { Rus } \\ & & & & & \end{array}$

$\begin{array}{llllll}16 & \text { Chicoric acid } & 6 & 12 & 34 & \text { Anti-HIV }\end{array}$

CID: 5281764

17 Tiliroside $\quad 7 \quad 13 \quad 43 \quad$ Anti-inflammatory $\quad$ Rosa canina

CID: 5320686

18 Glycyrrhizic acid $8 \quad 16 \quad 58 \quad \begin{aligned} & \begin{array}{l}\text { Anti-allergic, antiviral and } \\ \text { anti-inflammatory }\end{array} \\ & \text { Licorice }\end{aligned}$

CID: 14982

19 Hyperin $\quad 8 \quad 12 \quad 33 \quad$ Anti-inflammatory Rosa canina

CID: 133568467

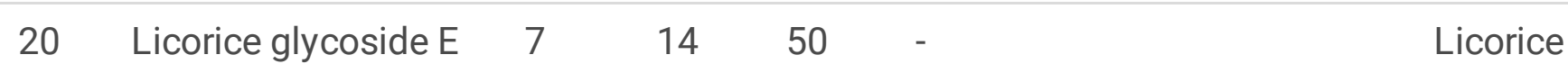

CID: 101938909

21 Rosmarinic acid $\quad 5 \quad 8 \quad 26 \quad$ Anti-inflammatory, antiviral Peperminte

CID: 5281792

\begin{tabular}{|c|c|c|c|c|c|c|}
\hline 22 & $\begin{array}{l}\text { Syringin } \\
\text { CID: } 5316860\end{array}$ & 5 & 9 & 26 & $\begin{array}{l}\text { Immunopotentiating, } \\
\text { immunostimulatory, } \\
\text { radioptotective }\end{array}$ & Ginseng \\
\hline
\end{tabular}

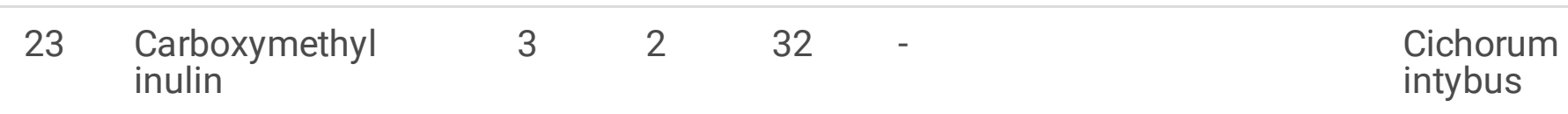

CID: 446984

24 Rutin $10 \quad 16 \quad 43 \quad$ Anti-inflammatory Rosa canina

CID: 5280805

25 Quercetin $\quad 5 \quad 7 \quad 22 \quad$ Anti-inflammatory $\quad$ Rosa canina

CID: 5280343

\begin{tabular}{|c|c|c|c|c|}
\hline Rhamnetin & 4 & 7 & 23 & $\begin{array}{l}\text { Anti-inflammatory, } \\
\text { antioxidant }\end{array}$ \\
\hline
\end{tabular}




\begin{tabular}{|c|c|c|c|c|c|c|}
\hline 27 & $\begin{array}{l}\text { beta- Sitosterol } \\
\text { CID: } 222284\end{array}$ & 1 & 1 & 30 & $\begin{array}{l}\text { Anti-carcinogenic, anti- } \\
\text { atherogenic }\end{array}$ & $\begin{array}{l}\text { Cichorum } \\
\text { intybus }\end{array}$ \\
\hline 28 & $\begin{array}{l}\text { Sageone } \\
\text { CID: } 6481824\end{array}$ & 2 & 3 & 22 & Anti- HIV-1 & Sage \\
\hline 29 & $\begin{array}{l}\text { Apigenin } \\
\text { CID: } 5280443\end{array}$ & 3 & 5 & 20 & $\begin{array}{l}\text { Anti-HSV, Anti-ADV, Anti- } \\
\text { HBV }\end{array}$ & Basill \\
\hline 30 & $\begin{array}{l}\text { Oleanolic acid } \\
\text { CID: } 10494\end{array}$ & 2 & 3 & 33 & $\begin{array}{l}\text { Antiviral, Anti-HIV, Anti- } \\
\text { influenza }\end{array}$ & Rosemary \\
\hline 31 & $\begin{array}{l}\text { Deoxylactucin } \\
\text { CID: } 442196\end{array}$ & 1 & 4 & 19 & Antifungal, & $\begin{array}{l}\text { Cichorum } \\
\text { intybus }\end{array}$ \\
\hline 32 & $\begin{array}{l}\text { Sambucus nigra } \\
\text { Degraded } \\
\text { cyanogenic } \\
\text { glycosides (2'- } \\
\text { Epimer) } \\
\text { CID: } 131751786\end{array}$ & 2 & 9 & 25 & $\begin{array}{l}\text { Anti-influenza virus, reducer } \\
\text { of upper } \\
\text { respiratory symptoms }\end{array}$ & $\begin{array}{l}\text { Black elderberry } \\
\text { (Sambucus } \\
\text { nigra) }\end{array}$ \\
\hline 33 & $\begin{array}{l}\text { Luteine } \\
\text { (Xanthophyll) } \\
\text { CID: } 5368396\end{array}$ & 2 & 2 & 42 & anti-inflammatory & Rosa canina \\
\hline 34 & $\begin{array}{l}\text { Shogaol } \\
\text { CID: } 5281794\end{array}$ & 1 & 3 & 20 & $\begin{array}{l}\text { anti-inflammatory, } \\
\text { antimicrobial }\end{array}$ & Ginger \\
\hline 35 & $\begin{array}{l}\text { Theophylline } \\
\text { CID: } 2153\end{array}$ & 1 & 3 & 13 & $\begin{array}{l}\text { Bronchodilator \& } \\
\text { Vasodilator Agents }\end{array}$ & $\begin{array}{l}\text { amellia sinensis } \\
\& \text { Coffea } \\
\text { arabica }\end{array}$ \\
\hline 36 & $\begin{array}{l}\text { Carvacrol } \\
\text { CID: } 10364\end{array}$ & 1 & 1 & 11 & $\begin{array}{l}\text { Anti-MNV, Anti-RSV } \\
\text { Anti-HSV-1, }\end{array}$ & Oregano \\
\hline 37 & $\begin{array}{l}\text { Menthol } \\
\text { ZINC000001482164 }\end{array}$ & 1 & 1 & 11 & Anti-inflammatory, antiviral & Peperminte \\
\hline 38 & $\begin{array}{l}\text { Germacrene D } \\
\text { CID: } 5373727\end{array}$ & 0 & 0 & 15 & $\begin{array}{l}\text { Antiviral, antifungal, } \\
\text { antibacterial, }\end{array}$ & $\begin{array}{l}\text { Myrtus } \\
\text { communis }\end{array}$ \\
\hline
\end{tabular}




\begin{tabular}{|lllllll|}
39 & $\begin{array}{l}\text { trans-Pinocarveol } \\
\text { CID } 88302\end{array}$ & 1 & 1 & 11 & antimicrobial activity & $\begin{array}{l}\text { Erodium } \\
\text { cicutarium }\end{array}$ \\
\hline 40 & $\begin{array}{l}\text { Diallyl trisulfide } \\
\text { ZINC000001531082 }\end{array}$ & 0 & 2 & 8 & Anticancer \& antiviral & Garlic \\
\hline
\end{tabular}

a All of the pharmaceutical function and sources information are recorded from PubCheme except the ligands containing references which are mentioned in supplementary information.

\subsection{Preparation of inhibitors and targets}

ADT converts PDB files of the ligands and receptors to the AutoDock Vina program ${ }^{[23]}$. We use Vina in this study, inputs in PDBQT format during the process naming the preparation of inhibitor and targetstructures. In this way, the PDB format extended to PDBQT via addition of partial charge and atom type to ATOM and HETATM records and recording the information of molecule rigid blocks. For the rigid docking running in this study, the rotatable bonds of ligand explicitly changed to non-rotatable bonds.

\subsection{Molecular docking study}

Molecular docking was performed using Vina program, version 1.1.2 on Windows 8.1 plat form (64-bit) with Asus X450C machine (Intel Pentium ULV 1.8 GHz, 4 GB memory). After preparing the PDBQT files, it is require to adjust the size and center point of a 3D box for ligand docking. In the set of ligands docked to the receptor, the grid center was selected as the middle point between extreme value of $x, y$, and $z$ coordinates. The grid dimensions were chosen so as to include all atoms of the ligand set, and then augmented by $10 \AA$ in $\pm x, \pm y$, and $\pm z$ directions ${ }^{[27]}$. The Num_modes was 50 for each ligand also. The options employed for other parameters were default. In especial, the grid spacing was $1.0 \AA$.

\subsection{Analysis of docking outcome}

Vina results, including multiple modes in PDBQT format, describe the docked ligand position, orientation and conformation. However, many visualization programs are not capable to read these files with nonstandard format, AutoDock Tools, discovery studio and LigPlot are freely available options used to visualize and analyze the Protein-ligand interactions in this project [ $\left.{ }^{[28]}\right]$.

\section{Results And Discussion}

Protein-ligand docking is a process in which protein related binding mode and affinity of ligand is predicted. Docking programs, as a key tool in computer-assisted drug design (CADD) and structural molecular biology, generally used for estimating the modeled system free energy and sampling its positional space by using a scoring function and an exploration method, respectively. AutoDock is one of the well established and open source protein-ligand docking softwares available. Moreover, it is an advantaous program in teaching, research anddesigning bioactive compounds. To improve the 
performance and accuracy of docking process, Vina is published under a free software license by the same group as AutoDock in $2010^{[23]}$ which was used in this project.

\subsection{Internal validation of molecular docking}

In order to substantiate the validation of docking method, the co-crystal ligand, Figure 3A, extracted from crystal structure of CoV-2019 main protease (6LU7) and re-docked. The binding poses of docked and crystallographic ligands are compared as illustrated in Figure 3B. It can be deduced from the figure 3B that the docking process is valid because the cognate ligand docked in the active site of target like crystallographic ligand with little difference in 3-methyl-2-pyrrolidinone ring benzene motif which is denoted by dash line.

\subsection{Molecular docking results}

Blocking of the SARS-CoV-2 main protease, 3CLpro, to prevent the synthesis of virus RNA and its replication is one of the current suggested therapies for Covide-19 dieses ${ }^{[29]}$. Based on the relevant target fetched from PDB, 6LU7, we screened potential bio-active synthetic and natural chemical compounds from PubChem and Zinc database using Vina. The ranking of AutoDock results is based on the lowest binding free energies and RMSD values of determined binding site. On the other hand, in Vina the RMSD value related to the top ranked pose which presents that the highest negative binding energy is 0 . Therefore, Vina ranks docking results based on the top ranked binding free energy not the relevant RMSD value ${ }^{[30]}$. The other binding affinity indicator, ligand efficiency (LE), is the size dependent binding energy and calculated by Eq.(1) ${ }^{[31]}$.

\section{$\mathrm{LE}=-\Delta \mathrm{Gb} / \mathrm{HAC} \mathrm{Eq} \cdot(\mathbf{1})$}

Where, $\Delta G_{b}$ stands for calculate binding energy and $H A C$ is heavy atom counts of a ligand, a number of non-hydrogen atoms that expresses ligand size. Based on this parameter, the larger ligand provide more interactions with target and show grater binding energy. However, the ligand efficiency of large ligands are reduced because these compounds interact with other regions beside 'hot spots' and may not necessarily be the most efficient binders ${ }^{[32]}$. Hence, Vina results to clarify the ligands with highest binding affinity to $3 C L$ pro are charted for this research based on lowest binding energy not subsequent RMSD values. In the same amount of binding energy, the ligands with higher ligand efficiency are preferred. Results are summarized in Table 3 and Table 4. As shown in Table 3, chemical compound 1 , Licofelone acyl glucuronide (antiinflammatory drug), Des(isopropylthiazolyl) hydantoin-oxazolidinone Ritonavir, delta-Bilirubin (antioxidant), Raltegravir (anti-HIV agent), Nigericin (antimicrobial and antibacterial agent) and Pradimicin A (anti-HIV and antifungal agents) had lowest binding energy. A number of other marketed drugs such as Rupintrivir (anti-HRV), Novobiocin (anti-bacterial agents), Megazone (antiinflammatory), Simeprevir (anti-HCV) and Amenamevir (anti- varicella-zoster virus and anti- herpes simplex virus types I \& II), showed relatively low binding energy which are worth studying more. However, some others like Sofosbuvir (anti-HCV), Isoxicam (anti-rheumatic), Fingolimod 
(immunomodulatory drug used to treat relapsing multiple sclerosis), Romidepsin (antineoplastic activity), and several anti-inflammatory drugs (Etoricoxib, Firocoxib, and Mesalazine) showed highest binding energy. For natural ligands extracted from various sources, Table 4, kappa-Carrageenan conformer, betaD-galactopyranosyl, Calycosin 7-0-glucoside, Gallic acid 3-cholesteryl ester, Spicoside A, Corilagin, Astragalin, Podophyllotoxin acetate, Rhamnetin and 3-0-beta-glucopyranoside showed lowest binding energy, respectively. Like synthetic ligands, natural ligands with highest estimated ligand efficiency do not have lower binding energy. According to the mentioned results, the small-molecule compounds containing lowest binding energy could probably have the inhibitory potential of 3CLprotarget and used to treat the SARS-COV-2. Based on the different theoretical and clinical studies, several research groups

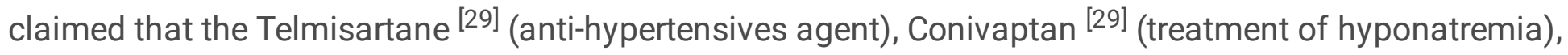
Chloroquine ${ }^{[33]}$ (antimalarial), Favipiravir ${ }^{[34]}$ (antiviral) and several anti-HIV agents such as Lopinavir ${ }^{[35]}$, Indinavir ${ }^{[34]}$, Saquinavir ${ }^{[36]}$, Ritonavir ${ }^{[37]}$ and Atazanavir ${ }^{[38]}$ could be the best $3 C L$ pro inhibitors.

Moreover, we docked these marketed drugs to compare them with other research group studies. The data from Table 3 showed that most of these drugs may have relatively acceptable binding affinity to $3 C L$ pro target, except the Chloroquine and Favipiravir. However, the applied receptor structure and scoring function are the same, the predicted binding constants are non-similar for different research groups. These differences are related to the not only different ligand and receptor preparation parameters but also to the different search procedure. For example, in preparation step, the different assigned charge, relaxation and flexibility of receptor besides the different applied united atoms, added charge type and number of bond torsions for ligand could not provide the same results. In docking step, the exhaustiveness and randomness of the search procedure in addition to the size and centering of the grid box could increase these differences, as well ${ }^{[39]}$. If we want to look on the bright side, the various binding energy estimated by different groups provide valuable information for further computational and experimental studies.

Table 3. The binding energy and ligand efficiency (LE) indices of synthetic ligands docked to 3CLpro receptor. The binding energy of cognate ligand and ligand efficiency are $-13.1 \mathrm{Kcal} / \mathrm{mol}$ and 0.27 , respectively. 


\begin{tabular}{|llllllllllll|}
\hline No. & $\Delta \mathrm{G}$ & $\mathrm{LE}$ & No. & $\Delta \mathrm{G}$ & $\mathrm{LE}$ & No. & $\Delta \mathrm{G}$ & $\mathrm{LE}$ & No. & $\Delta \mathrm{G}$ & $\mathrm{LE}$ \\
\hline 1 & -10.9 & 0.23 & 14 & -8.7 & 0.17 & 27 & -8.3 & 0.16 & 40 & -7.4 & 0.20 \\
\hline 2 & -10.3 & 0.26 & 15 & -8.7 & 0.17 & 28 & -8.2 & 0.22 & 41 & -7.3 & 0.21 \\
\hline 3 & -10.0 & 0.24 & 16 & -8.6 & 0.25 & 29 & -8.2 & 0.18 & 42 & -7.3 & 0.32 \\
\hline 4 & -9.9 & 0.23 & 17 & -8.6 & 0.23 & 30 & -8.2 & 0.19 & 43 & -7.2 & 0.29 \\
\hline 5 & -9.8 & 0.31 & 18 & -8.5 & 0.20 & 31 & -8.1 & 0.19 & 44 & -7.2 & 0.30 \\
\hline 6 & -9.8 & 0.19 & 19 & -8.5 & 0.19 & 32 & -8.1 & 0.24 & 45 & -7.1 & 0.32 \\
\hline 7 & -9.8 & 0.16 & 20 & -8.4 & 0.17 & 33 & -8.0 & 0.16 & 46 & -6.9 & 0.31 \\
\hline 8 & -9.6 & 0.22 & 21 & -8.4 & 0.38 & 34 & -7.9 & 0.10 & 47 & -6.7 & 0.29 \\
\hline 9 & -9.5 & 0.21 & 22 & -8.4 & 0.21 & 35 & -7.9 & 0.27 & 48 & -6.7 & 0.19 \\
\hline 10 & -9.4 & 0.21 & 23 & -8.4 & 0.23 & 36 & -7.7 & 0.35 & 49 & -5.6 & 0.51 \\
\hline 11 & -9.3 & 0.21 & 24 & -8.3 & 0.27 & 37 & -7.5 & 0.33 & 50 & -5.3 & 0.48 \\
\hline 12 & -9.0 & 0.24 & 25 & -8.3 & 0.17 & 38 & -7.4 & 0.27 & & & \\
\hline 13 & -8.9 & 0.20 & 26 & -8.3 & 0.17 & 39 & -7.4 & 0.28 & & & \\
\hline
\end{tabular}

Table 4. The binding energy and ligand efficiency (LE) indices of natural ligands docked to 3CLpro receptor.

\begin{tabular}{|llllllllllll|}
\hline No. & $\Delta \mathrm{G}$ & $\mathrm{LE}$ & No. & $\Delta \mathrm{G}$ & $\mathrm{LE}$ & No. & $\Delta \mathrm{G}$ & $\mathrm{LE}$ & No. & $\Delta \mathrm{G}$ & $\mathrm{LE}$ \\
\hline 1 & -11.5 & 0.23 & 11 & -10.0 & 0.15 & 21 & -9.3 & 0.36 & 31 & -7.3 & 0.38 \\
2 & -11.2 & 0.22 & 12 & -9.7 & 0.29 & 22 & -8.9 & 0.34 & 32 & -6.5 & 0.15 \\
3 & -10.5 & 0.32 & 13 & -9.7 & 0.30 & 23 & -8.8 & 0.27 & 33 & -6.5 & 0.15 \\
4 & -10.2 & 0.26 & 14 & -9.7 & 0.23 & 24 & -8.8 & 0.20 & 34 & -6.0 & 0.30 \\
\hline 5 & -10.2 & 0.34 & 15 & -9.7 & 0.30 & 25 & -8.7 & 0.39 & 35 & -5.16 & 0.43 \\
6 & -10.2 & 0.23 & 16 & -9.6 & 0.28 & 26 & -8.4 & 0.36 & 36 & -5.2 & 0.4 \\
7 & -10.2 & 0.34 & 17 & -9.5 & 0.22 & 27 & -8.4 & 0.28 & 37 & -5.1 & 0.4 \\
\hline 8 & -10.1 & 0.31 & 18 & -9.4 & 0.16 & 28 & -8.0 & 0.36 & 38 & -5.1 & 0.34 \\
\hline 9 & -10.1 & 0.30 & 19 & -9.4 & 0.28 & 29 & -7.9 & 0.39 & 39 & -4.6 & 0.42 \\
\hline 10 & -10.0 & 0.34 & 20 & -9.3 & 0.19 & 30 & -7.9 & 0.24 & 40 & -3.5 & 0.44 \\
\hline
\end{tabular}




\subsection{Analysis of molecular docking results}

The 3CLpro or Nsp5, the COVID-19 main protease, which has important role in virus RNA synthesis and replication is one of the most important targets for the introduction of efficient small-molecule inhibitors. The target consist of I, II and III domain identified by residues 1-101, residues 102-184 and residues 201-301, respectively. A long loop between domains II and III and the active site between domains I and II are the other characteristics of $3 C L$ pro target ${ }^{[40]}$. The interactions of $3 C L$ pro target with reference ligand, $\mathrm{N} 3$, and suggested bioactive inhibitors are discussed in the coming sections. For comparison, the 2D images of crystallographic and re-docked ligands interaction with active site of receptor are illustrated in (Figure S1). The further hydrogen bond between $\mathrm{N}_{5}$ of methyl-2-Pyrrolidinone motif in cognate ligand and Glu166 is a cause of distinct difference between crystallographic and cognate one which is identified by dashed red cycle in Figure 3. The other indistinct differences are include hydrophobic interactions between $\mathrm{C}_{8}$ and $\mathrm{C}_{17}$ with Pro168 and Met165, respectively. This means the physiological conditions especially various solvents may influence on the ligand-protein interactions in crystal structure.

\subsubsection{Synthetic compound analysis}

The similarity of binding mode for potentially more effective inhibitors containing lower binding energy was further investigated. The chemical compound 1 with lowest binding energy $(-10.9 \mathrm{Kcal} / \mathrm{mol})$ showed relatively similar binding mode but Licofelone acyl glucuronide with binding energy of -10.5 $\mathrm{Kcal} / \mathrm{mol}$ showed less similar binding mode in comparison to reference ligand (Table3, Figure4). The superposition images of Ritonavir impurity $\mathrm{H}$ [EP] and delta-Bilirubin illustrated their lower binding similarity modes, as well (Figure S2).

It is surprising that, Raltegravir (anti HIV agent) with highest binding energy $(-9.8 \mathrm{Kcal} / \mathrm{mol})$ toward the above mentioned compounds has more binding mode similarity and could be one of the best candidate drugs for SARS-CoV-2 (Table3, Figure 5A).

In other research studies, the marketed drugs such as Lopinavir, Indinavir, and Ritonavir have been reported as potential inhibitors to block $3 C L$ pro of SARS-CoV-2. The results of this study containing molecular docking and binding mode similarity based on the X-ray crystallographic structure of Mpro, are compatible with the other predictions ${ }^{[37]}$ (Table 3, Figure S3). However, Ritonavir with an estimated binding energy of $-8.0 \mathrm{kcal} / \mathrm{mol}$ could be the best candidate drug due to high similarity of binding mode.

The detailed investigation of ligand and receptor interactions uncover the affinity of suggested inhibitors and facilitate the chance of introducing potential drug candidates for Mpro blocking. As shown in Figure $6 \mathrm{~A}$ and Figure S4A the compound 1 fitness with active pocket of receptor is well. A number of $\pi-\pi$ and $\pi$-alkyl hydrophobic interactions between ligand and amino acids such as $\mathrm{Gln} 189, \mathrm{G} \ln 166$, His41, Cys145, His164, Met165, Met49, Arg188 and Asp167 conform the compound in the pocket of receptor. The predicted hydrogen bonds of Asn 142 with oxygen atoms and Thr26 with hydrophilic hydrogen atom of the compound, guarantee the conformer stabilization, also. The presence of 4 hydrogen bond donor 
and 6 hydrogen bond acceptor atoms in the ligand structure and hydrophilic amino acids provide these hydrophilic environment (Table1 and Figure7A).

Anti-inflammatory drug Licofelone acyl glucuronide which is the relevant inhibitor of CYP2C8 [ ${ }^{[41]}$ was predicted to bind to $3 C L$ pro with low binding energy (Scores $=-10.3 \mathrm{Kcal} / \mathrm{mol})$. The generated docking model shows that the drug conjunction with the active site of the enzyme is created by hydrogen bond between hydroxyl group of drug and Glu166 (Figure 6B, and Figure S4B). Moreover, lots of interactions between drug and hydrophobic amino acids, like His41 ( $\pi$-sigma), Met49 ( $\pi$-sulfur, and Cys 145 and Met165 (Alkyl \& $\pi$-alkyl) imply that it may be a potent 3CLpro inhibitor. The Figure 7B shows the 3D image of provided hydrophobic environment.

The other compound, Ritonavir impurity $\mathrm{H}$ [EP], with docking scoring of $(-10.0 \mathrm{Kcal} / \mathrm{mol})$ was well fitted into the active pocket of $3 C L$ pro, also. The Hydrogen bonds between GIn189 and Ser46 with the carbonyl group of the compound and the hydrophobic bonds between ligand atoms and Leu141(Amide- $\pi$ stacked), Cys145 ( $\pi$-alkyl) and His164 (Carbon hydrogen bond) stabilize the ligand conformation and introduce it as a good inhibitor for target (Figure 6C and Figure S4C).

Moreover, the results of delta-Bilirubin docking in the active site of 3CLpro were analyzed and the output was illustrated in Figures 6D and Figure S4D. The images show two hydrogen bond between ligand N-H groups and GIn189 and Leu167, a $\pi$-anion bond between 5member ring of ligand and Glu166 and several alkyl and $\pi$-alkyl bonds related to for example, Cys145, Met165 and Met49. This hydrophobic environment besides two hydrogen bond could ensure the stability of ligand and receptor complex. Our findings revealed that all of the analyzed compounds possess docking sites that strongly overlap with the protein pockets, and could be potential therapeutic agents.

Moreover, the marketed drugs like Lopinavir and Indinavir provide more hydrophilic and hydrophobic interactions with different aminoacids, there Figures are not shown in this study, and conform their stabilization in the pocket. According to Table1, Ritonavir with 4 hydrogen bond donor and 9 hydrogen bond acceptor atoms, provide no more hydrogen bonds with amino acids and has less hydrophobic interactions and consequently it could not be stabilized in the pocket of target. Because Licofelone acyl glucuronide, delta-Bilirubin, Lopinavir and Indinavir have been used in clinical practices with limited toxicity, we recommend them to treat COVID-19.

\subsubsection{Analysis of natural ligands}

According to the docking results, lots of natural compounds from different sources were predicted to be $3 C L$ pro inhibitors with high binding affinity (Table4) through virtual ligand screening. The binding similarity mode and docking result analysis of a number of these compounds containing highest negative binding energy were studied in detail.

The antiviral activity of kappa-Carrageenan extracted from Red Algae against myxoviridae, paramyxoviridae, adenoriridae and coronaviridae increases the chance of this ligand to inhibit the SARS- 
Cov-2 main protease ${ }^{[42]}$. One of the conformers of this compound, ZINC96061851, with lowest binding energy $(-11.5 \mathrm{Kcal} / \mathrm{mol})$ showed similar binding mode when overlapped with reference ligand (Figure $8 A)$.

For beta-D-galactopyranosyl ${ }^{[43]}(-11.2 \mathrm{Kcal} / \mathrm{mol})$ with anti-inflammatory effect, which is extracted from Rosa canina $L$., the binding similarity mode is relatively good (Figure S5A). Rosa canina $L$.,, which is called Nasrarane vahshi, is Rosaceae family plant and grows Kordestan Province, Iran ${ }^{[44]}$.

The extracted compound from the Astragalus plant, Calycosin 7-0-glucoside ${ }^{[45]}$, which is proved to have antiviral activity might be a candidate for inhibiting target showed relatively similar binding mode, as well (Figure S5B).

Cichorum intybus $L$. is the scientific name of Asteraceae family plant, locally called Sechertghi, and find in the north of Iran, Turkmen Sahra ${ }^{[44]}$. Spicoside A ${ }^{[46]}$, plant extract, which has the Neuroprotective potency docked into the relevant target and gained $-10.2 \mathrm{Kcal} / \mathrm{mol}$ binding energy. Unfortunately, the similarity of binding mode for this ligand was lower. The superposition figure of binding mode similarity for this ligand is not shown in this study.

Ficus carica L. is another Iranian medicinal plant that grows in Golestan, Fars and Khuzestan Province and locally called Anjeir ${ }^{44]}$. The plant extract, Gallic acid 3-cholesteryl ester ${ }^{[47]}$, whit proven antimicrobial activity showed well binding affinity and higher similar binding mode when docked to $3 C L$ pro receptor (Figure 8B).

The 2D images of docking result analysis for beta-D-galactopyranosyl are illustrated in Figure 9A and Figure S6A. It can be inferred from the images that the hydroxyl and carboxyl groups of ligand provide hydrogen bonds with Ser46, Leu141, GIn189 and Glu166. The presence 9 hydrogen bond donor and 19 hydrogen bond acceptor atoms in the ligand structure conform the existence of more hydrophilic bonds in the pocket. The interactions of carbon atoms on the ligand structure with amino acids such as Thr24, Thr26, Glu166 created carbon hydrogen bonds, also. These interactions and other hydrophobic interactions such as $\pi$-alkyl one between 5 member ring of ligand and Cys 145 cause beta-Dgalactopyranosyl to be a good inhibitor for target blocking.

The different type of bonds between ligand and receptor based on the Figure 9B and Figure S6B for Calycosin 7-0-glucoside are include:

- Hydrogen bonds from the interaction of Cys145, Ser144, Gly143and GIn189 with different hydroxyl groups of ligand.

- Unfavorable donor-donor bond for Ser144 and Gly143 and hydroxyl groups of ligand.

- Amid- $\pi$ stacked of ligand aromatic ring and Gln189.

- Hydrophobic bonds of ligand atoms with Asn142, Met165, Glu166, Thr190 and Aln191. 
The further analysis of docking results for Spicoside A illustrated in Figure $9 \mathrm{C}$ and Figure $\mathrm{S} 6 \mathrm{C}$ that showed more hydrogen bonds between hydroxyl and oxygen groups of ligand and different amino acids including Ser144, Asn142, Thr26, Gln189, Gly143, Lue141 and Cys145. In addition, hydrophobic interactions with Phe140, Thr26, Thr25, Glu166, Asn142 and Cys145 may further direct the favorite conformation of this inhibitor.

The data from Figure 9D and Figure S6D showed three hydrogen bond for Ser46 and one hydrogen bond for Thr24, Thr25 and Thr45. The alkyl bonds between carbon atoms of ligand and Cys145 and Met165 are the other characteristics of analysis of docking results.

It's worth mentioning that, as shown in Figure 10, Thr24, Glu166 and Asn142 formed five hydrogen bonds with the oxygen, hydroxyl and sulphate groups of the kappa-Carrageenan conformer. The hydrophobic interactions between the compound atoms and Leu167, Met165, Thr190, Pro168, GIn189, Cys145, Met49 and Thr26 may further stabilize its conformation (Figure 9B).

The results of analysis indicated that all of the above mentioned compounds could be connected to the active site of target via desirable and strong hydrophilic and hydrophobic bonds. These strong interactions are related to the affinity of compound atoms to various amino acids presence in the conserved region which are the key factors in enzymatic catalysis. The compounds could be suitable and potent substitutes for synthetic drugs to treat new coronavirus infections due to their natural origin and fewer side effects.

\section{Conclusion}

The emergence of COVID-19 as a potential global health threat caused massive disruptions to the nations' health and economy. The employment of effective and time-efficient protein-ligand docking process to discover potent anti-COVID-19 compounds at the shortest possible time is critical. The aim of this study was the construction of 50 synthetic compounds with various pharmacological usage including approved drugs and those undergoing clinical trials, and 40 natural compounds database, molecular docking of selected compounds, and evaluation of their binding interaction against the SARSCoV-2 3CLpro. Accordingly, the compound 1, licofelone acyl glucuronide (antiinflammatory drug), Ritonavir impurity H [EP], delta-Bilirubin (antioxidant), Raltegravir (anti-HIV agent), Nigericin (antimicrobial and antibacterial agent) and Pradimicin A (anti-HIV and antifungal agents) had lowest binding energy. For natural ligands, kappa-Carrageenan conformer, beta-D-galactopyranosyl, calycosin 7-0-glucoside, gallic acid 3-cholesteryl ester, Spicoside A, Corilagin, astragalin, podophyllotoxin acetate, Rhamnetin and 3-0-beta-glucopyranoside showed the lowest binding energy, respectively. Moreover, the results showed that among investigated marketed drugs, Telmisartane, Conivaptan, Lopinavir, Indinavir, Saquinavir, Ritonavir and Atazanavir may have relatively low binding energy. The similarity of binding mode and ligand-receptor interactions were investigated for potential inhibitors, optionally. Compound 1, Raltegravir, kappa-Carrageenan conformer and Gallic acid 3-cholesteryl ester showed higher similarity binding mode, as well. The analysis of ligand-receptor interactions revealed that most studied compounds have the 
ability to bind to the target pocket. Overall, the compound 1, CID:134816013, was identified as the best inhibitor of $3 C L$ pro due to the lowest binding energy, highest similarity mode and more ligand-receptor interactions and introduced to further in-vitro and in-vivo studies. Moreover, the small-molecules like licofelone acyl glucuronide and delta-Bilirubin in addition to some of natural compounds with highest negative binding energy could probably have the inhibitory potential of $3 C L$ pro target and they have the potential to become an anti-COVID-19 clinical drug.

\section{Declarations}

\section{Conflicts of interest}

Authors declare that they have no conflict of interest.

\section{Acknowledgement}

This work was supported by the "Iran National Science Foundation: INSF".

\section{References}

[1]aJ. S. Kahn, K. McIntosh, Pediatr. Infect. Dis. J. 2005, 24, S223-S227; bC. Geller, M. Varbanov, R. E. Duval, Viruses 2012, 4, 3044-3068.

[2]aJ. Almeida, D. Berry, C. Cunningham, D. Hamre, M. Hofstad, L. Mallucci, K. Mclntosh, D. Tyrrell, Nature 1968, 220, 2; bL. S. Sturman, K. V. Holmes, Adv. Virus Res. (Elsevier), vol 28, 1983, pp. 35-112.

[3]C. S. Goldsmith, K. M. Tatti, T. G. Ksiazek, P. E. Rollin, J. A. Comer, W. W. Lee, P. A. Rota, B. Bankamp, W. J. Bellini, S. R. Zaki, Emerg. Infect. Dis. 2004, 10, 320.

[4]A. R. Fehr, S. Perlman, in Coronaviruses (Springer), 2015, pp. 1-23.

[5]B. W. Neuman, B. D. Adair, C. Yoshioka, J. D. Quispe, G. Orca, P. Kuhn, R. A. Milligan, M. Yeager, M. J. Buchmeier, J. Virol. 2006, 80, 7918-7928.

[6]B. W. Neuman, G. Kiss, A. H. Kunding, D. Bhella, M. F. Baksh, S. Connelly, B. Droese, J. P. Klaus, S. Makino, S. G. Sawicki, J. Struct. Biol. 2011, 174, 11-22.

[7]A. C. Wong, X. Li, S. K. Lau, P. C. Woo, Viruses 2019, 11, 174.

[8]aD. S. Hui, E. E. Azhar, T. A. Madani, F. Ntoumi, R. Kock, O. Dar, G. Ippolito, T. D. Mchugh, Z. A. Memish, C. Drosten, Int. J. Infect. Dis. 2020; bR. Lu, X. Zhao, J. Li, P. Niu, B. Yang, H. Wu, W. Wang, H. Song, B. Huang, N. Zhu, Lancet 2020, 395, 565-574.

[9]aJ. Cohen, Science 2020, 10; bP. Zhou, X.-L. Yang, X.-G. Wang, B. Hu, L. Zhang, W. Zhang, H.-R. Si, Y. Zhu, B. Li, C.-L. Huang, Nature 2020, 1-4. 
[10]aD. S. Hui, E. I Azhar, T. A. Madani, F. Ntoumi, R. Kock, O. Dar, G. Ippolito, T. D. Mchugh, Z. A. Memish, C. Drosten, Int. J. Infect. Dis. 2020, 91, 264-266; bW. H. Organization, "WHO Statement Regarding Cluster of Pneumonia Cases in Wuhan, China. Beijing: WHO", can be found under www.who.int. 2020.

[11]W. H. Organization, "Laboratory testing of human suspected cases of novel coronavirus ( $\mathrm{nCoV}$ ) infection: interim guidance" can be found under www.who.int., 2020.

[12]W. Ji, W. Wang, X. Zhao, J. Zai, X. Li, J. Med. Virol 2020.

[13]C. COVID, " Global Cases by Johns Hopkins CSSE. Вилучено з" can be found under https://gisanddata. maps. arcgis. com/apps/opsdashboard/index. htm/\#/bda7594 740fd40299423467b48e9ecf6.

[14]N. Zhu, D. Zhang, W. Wang, X. Li, B. Yang, J. Song, X. Zhao, B. Huang, W. Shi, R. Lu, N Engl. J. Med. 2020.

[15]Y. Shu, J. McCauley, Euro Surveill. 2017, 22.

[16]B. J. Bosch, R. van der Zee, C. A. de Haan, P. J. Rottier, J. Virol. 2003, 77, 8801-8811.

[17]X. Liu, B. Zhang, Z. Jin, H. Yang, Z. Rao, " The crystal structure of COVID-19 main protease in complex with an inhibitor N3. RCSB Protein Data Bank" can be found under https://doi.org/10.2210/PDB6LU7/PDB, 2020.

[18]aD. P. Han, A. Penn-Nicholson, M. W. Cho, Virology 2006, 350, 15-25; bX.-Y. Ge, J.-L. Li, X.-L. Yang, A. A. Chmura, G. Zhu, J. H. Epstein, J. K. Mazet, B. Hu, W. Zhang, C. Peng, Nature 2013, 503, 535-538; cW. Li, M. J. Moore, N. Vasilieva, J. Sui, S. K. Wong, M. A. Berne, M. Somasundaran, J. L. Sullivan, K. Luzuriaga, T. C. Greenough, Nature 2003, 426, 450-454.

[19]aA. S. Agrawal, T. Garron, X. Tao, B.-H. Peng, M. Wakamiya, T.-S. Chan, R. B. Couch, C.-T. K. Tseng, J. Virol. 2015, 89, 3659-3670; bJ. Zhao, K. Li, C. Wohlford-Lenane, S. S. Agnihothram, C. Fett, J. Zhao, M. J. Gale, R. S. Baric, L. Enjuanes, T. Gallagher, Proc. Natl. Acad. Sci. 2014, 111, 4970-4975.

[20]K. Anand, J. Ziebuhr, P. Wadhwani, J. R. Mesters, R. Hilgenfeld, Science 2003, 300, 1763-1767.

[21]al.-L. Lu, N. Mahindroo, P.-H. Liang, Y.-H. Peng, C.-J. Kuo, K.-C. Tsai, H.-P. Hsieh, Y.-S. Chao, S.-Y. Wu, J. Med. Chem. 2006, 49, 5154-5161; bB. Xia, X. Kang, Protein Cell. 2011, 2, 282-290; cD. Needle, G. T. Lountos, D. S. Waugh, Acta Crystallogr., Sect. D: Biol. Crystallogr. 2015, 71, 1102-1111.

[22]aT. Pillaiyar, M. Manickam, V. Namasivayam, Y. Hayashi, S.-H. Jung, J. Med. Chem. 2016, 59, 65956628; bA. K. Ghosh, K. Xi, K. Ratia, B. D. Santarsiero, W. Fu, B. H. Harcourt, P. A. Rota, S. C. Baker, M. E. Johnson, A.D. Mesecar, J. Med. Chem. 2005, 48, 6767-6771; cV. Kumar, K.-P. Tan, Y.-M. Wang, S.-W. Lin, P.-H. Liang, Bioorg. Med. Chem. Lett. 2016, 24, 3035-3042. 
[23]0. Trott, A. J. Olson, J. Comput. Chem. 2010, 31, 455-461.

[24]aR. E. Dizaji, A. Rezaie kehkhaie, M. Taqi khammar, R. shirazinia, Int J Plant Sci Hor., 2019, 1, 56-62; bA. Ameri, G. Heydarirad, J. Mahdavi Jafari, A. Ghobadi, H. Rezaeizadeh, R. Choopani, Pharm. Biol. 2015, 53, 615-623; cJ. Patocka, Z. Navratilova, Pharmacology 2019, 20; dM. Farahani, Q. Branch, I. Azad, Zahedan J. Res. Med. Sci. 2013, 15, 46-48; eM. Abolhassani, Arch. Med. Sci.: AMS 2010, 6, 366.

[25]G. W. Price, P. S. Gould, A. Marsh, J. Chem. Educ., 2014, 91, 4, 602-604.

[26]G. M. Morris, R. Huey, W. Lindstrom, M. F. Sanner, R. K. Belew, D. S. Goodsell, A. J. Olson, J. Comput. Chem. 2009, 30, 2785-2791.

[27]T. Gaillard, J. Chem. Inf. Model. 2018, 58, 1697-1706.

[28]A. C. Wallace, R. A. Laskowski, J. M. Thornton, Protein Eng. Des. Sel. 1995, 8, 127-134.

[29]C. Wu, Y. Liu, Y. Yang, P. Zhang, W. Zhong, Y. Wang, Q. Wang, Y. Xu, M. Li, X. Li, Acta Pharm. Sin. B. 2020.

[30]A. Ascone, R. Sakidja, Int. J. Comput Biol. Drug Des. 2017, 10, 207-224.

[31]R. Alikhani, N. Razzaghi-Asl, A. Ramazani, Z. Hosseinzadeh, J. Mol. Struct. 2018, 1164, 9-22.

[32]M. Orita, K. Ohno, M. Warizaya, Y. Amano, T. Niimi, in Methods in enzymology (Elsevier), Vol. 493, 2011, pp. 383-419.

[33]J. Gao, Z. Tian, X. Yang, Biosci. Trends. 2020.

[34]Y.-C. Chang, Y.-A. Tung, K.-H. Lee, T.-F. Chen, Y.-C. Hsiao, H.-C. Chang, T.-T. Hsieh, C.-H. Su, S.-S. Wang, J.-Y. Yu, 2020, DOI 10.20944/preprints202002.0242.v1.

[35]J. Wang, 2020, DOI 10.26434/chemrxiv.11875446.v1.

[36]T. Sekhar, 2020, DOI 10.20944/preprints202002.0418.v1.

[37]Z. Wang, X. Chen, Y. Lu, F. Chen, W. Zhang, Biosci. Trends. 2020.

[38]B. R. Beck, B. Shin, Y. Choi, S. Park, K. Kang, 2020, DOI 10.1101/2020.01.31.929547.

[39]L. Masters, S. Eagon, M. Heying, J. Mol. Graph. Model. 2020, 107532.

[40]H. Yang, M. Yang, Y. Ding, Y. Liu, Z. Lou, Z. Zhou, L. Sun, L. Mo, S. Ye, H. Pang, Proc. Natl. Acad. Sci. 2003, 100, 13190-13195.

[41]Y. Ma, Y. Fu, S. C. Khojasteh, D. Dalvie, D. Zhang, J. Med. Chem. 2017, 60, 8691-8705. 
[42]A. a. P.-G. Grassauer, Eva, US, 2009.

[43]K. Winther, A. S. V. Hansen, J. Campbell-Tofte, Botanics 2016, 6, 11.

[44]M. Asadi-Samani, M.-T. Moradi, M. Bahmani, M. Shahrani, Int.J. PharmTech Res. 2016, 9, 427-434.

[45]H. Zhu, Y. Zhang, G. Ye, Z. Li, P. Zhou, C. Huang, Biol. Pharm. Bull. 2009, 32, 68-73.

[46]M. Naoi, M. Shamoto-Nagai, W. Maruyama, Future Neurol. 2019, 14, FNL9.

[47]S. Choubey, L. R. Varughese, V. Kumar, V. Beniwal, Pharm. Pat. Anal. 2015, 4, 305-315.

Figures
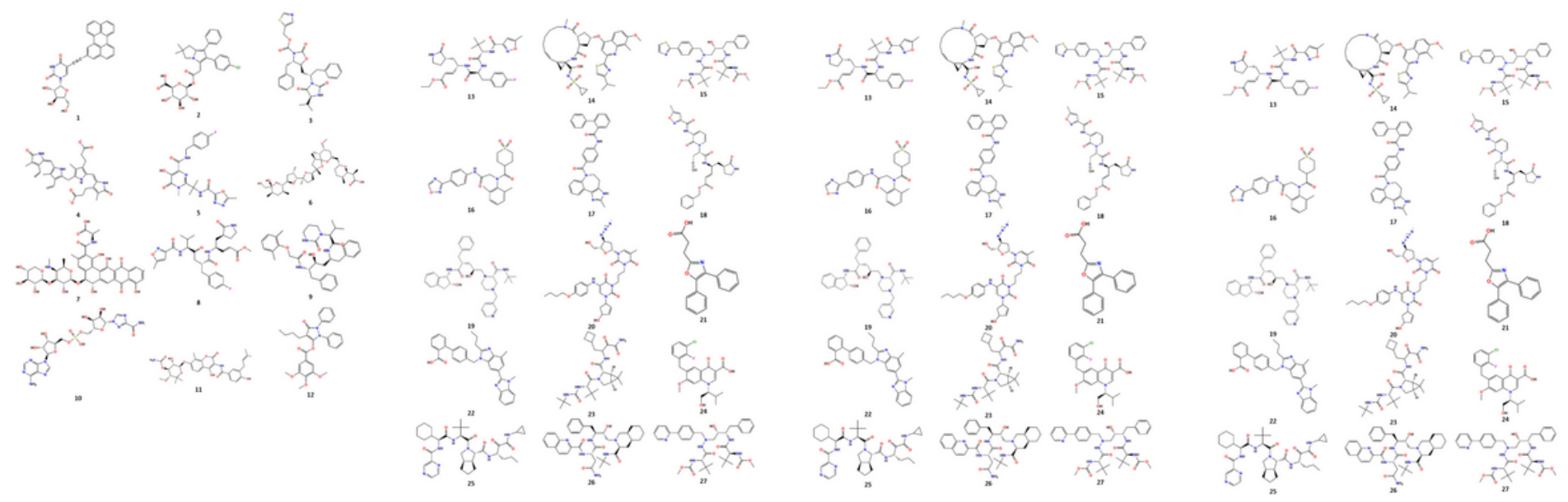

\section{Figure 1}

2D structure of synthetic chemical compound as 3CLpro inhibitor candidates

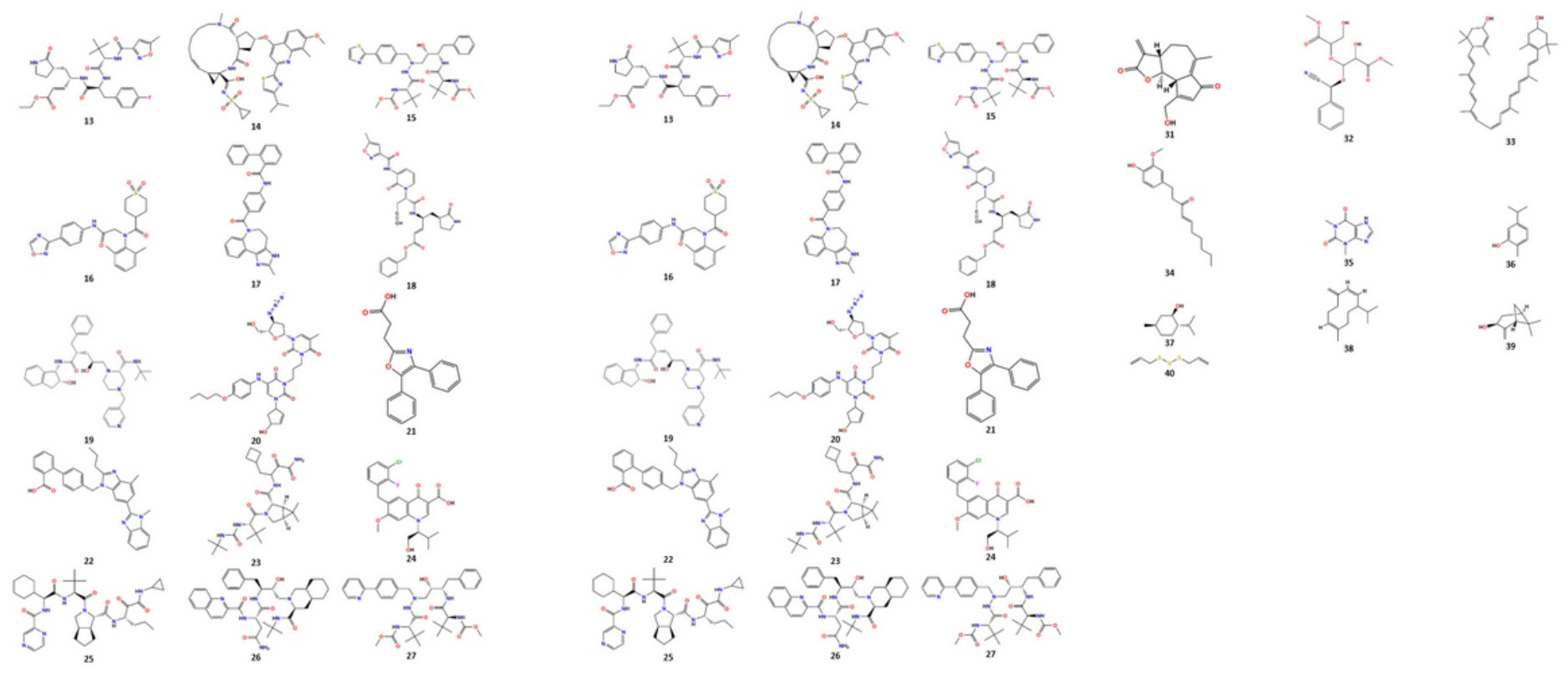


Figure 2

2D structure of 3CLpro inhibitors from natural sources

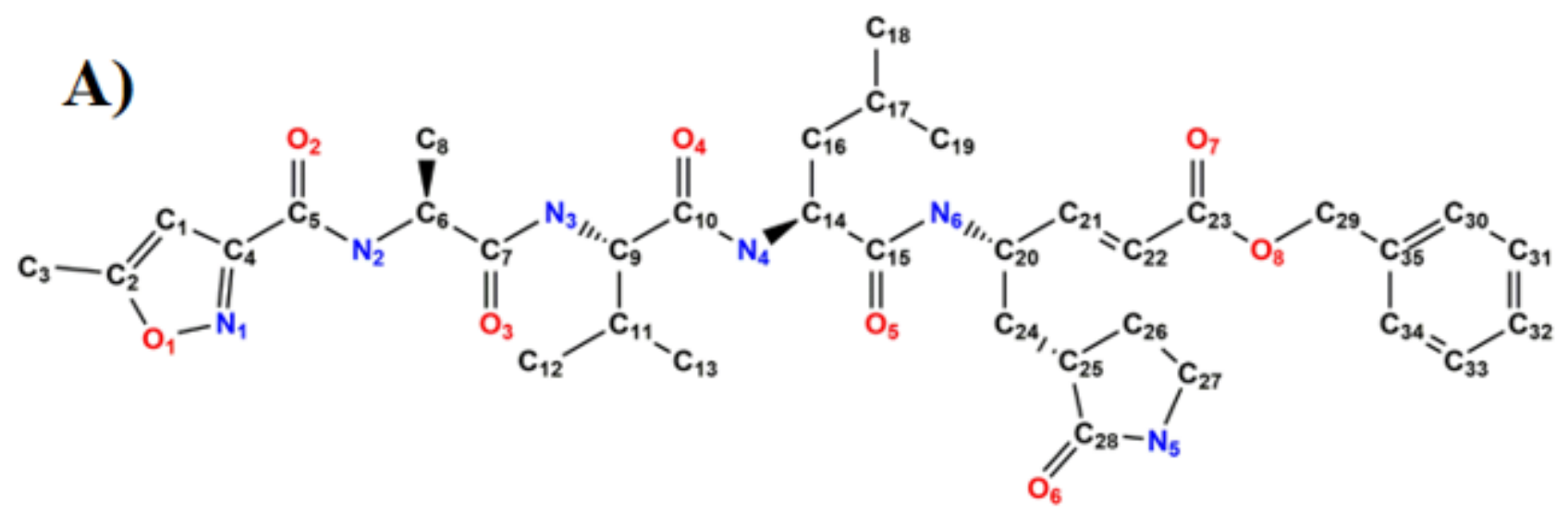

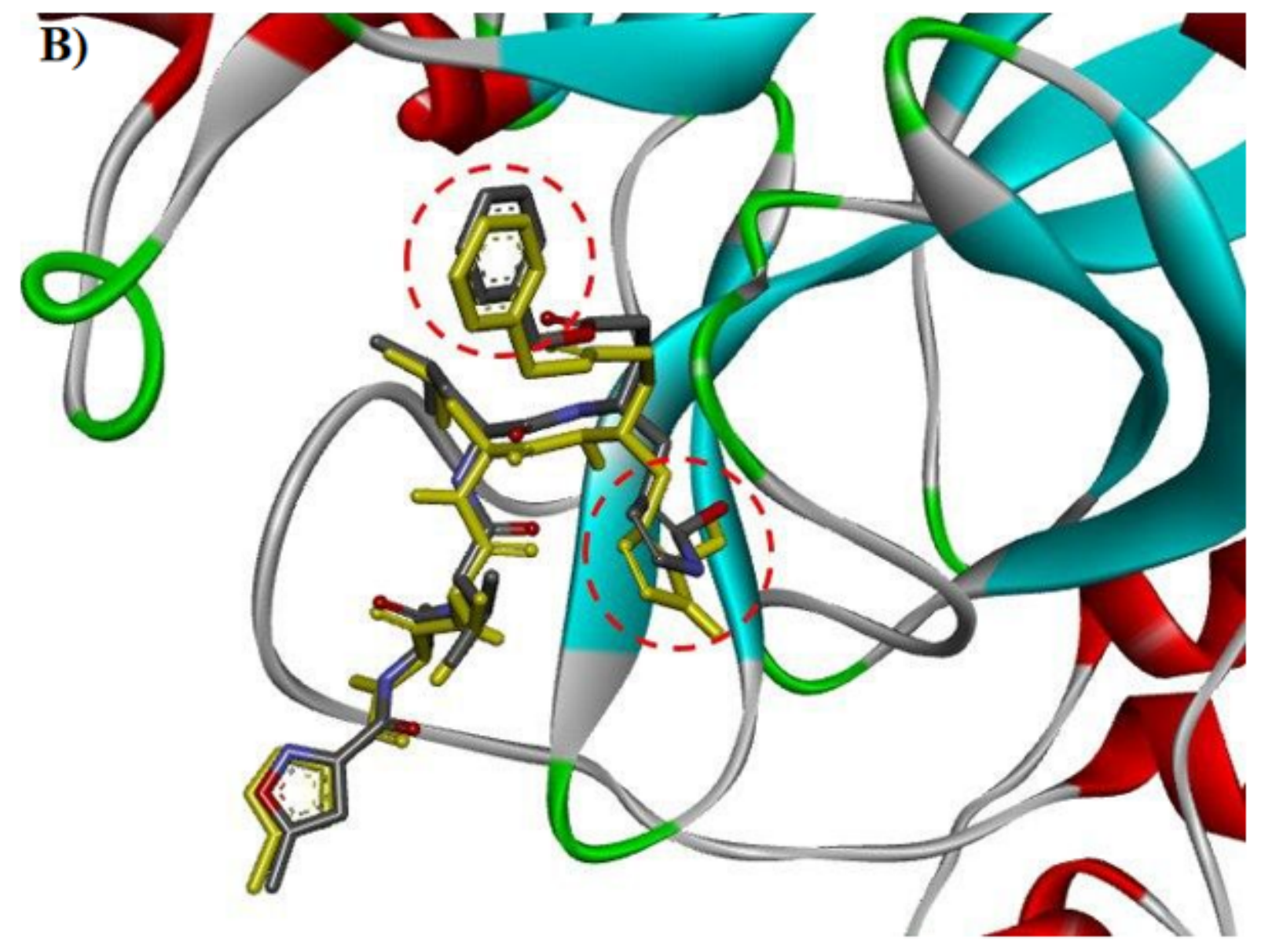

Figure 3

A) 2D structure of cognate ligand (N3 inhibitor) and B) The Superposition of docked ( $)$ and crystallographic ( $)$ conformation of cognate ligand in the binding pose of relevant receptor 


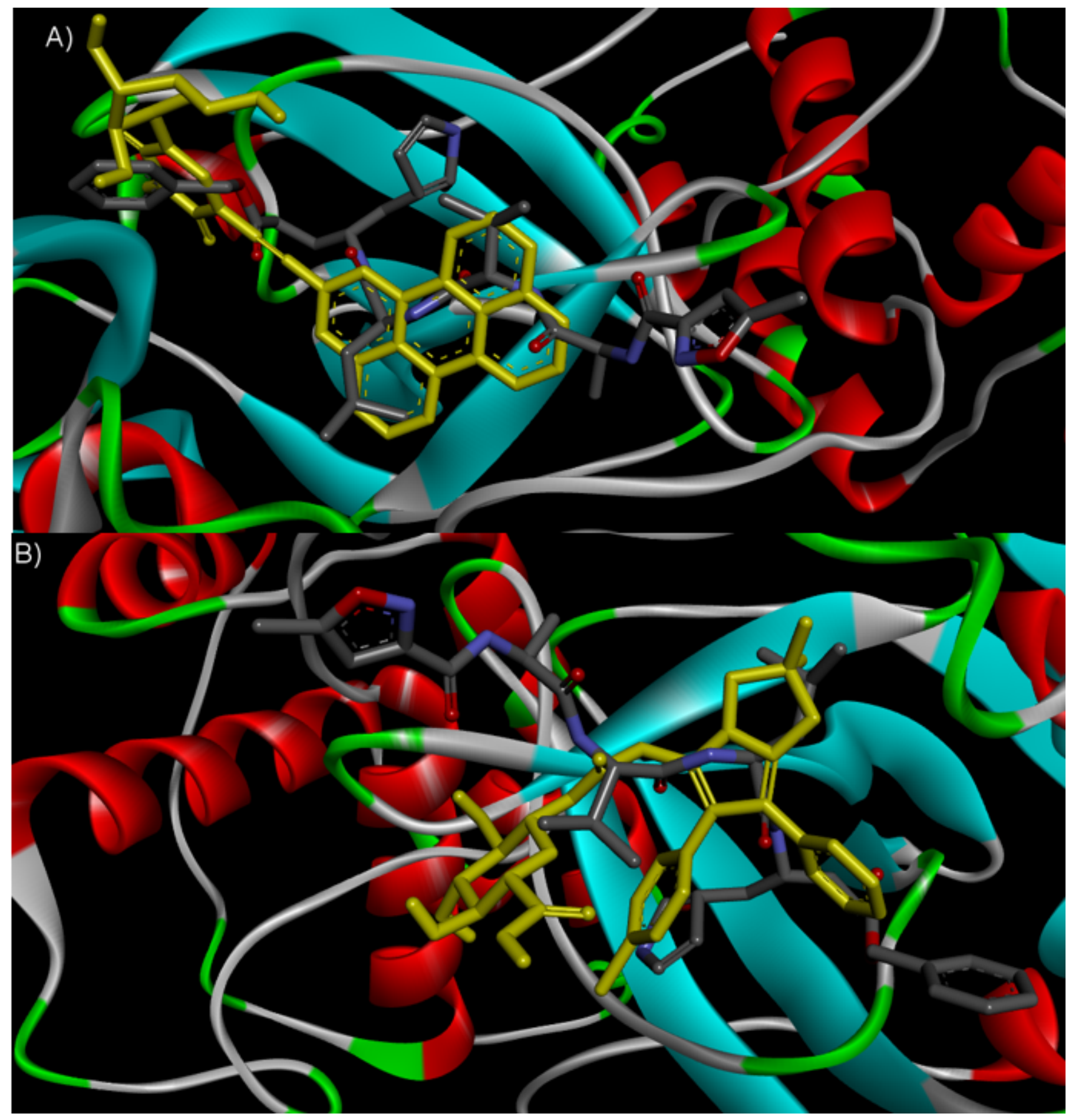

Figure 4

The overlap images of crystallographic binding mode of ligand N3 ( $)$ and predicted binding mode of potential inhibitors ( $(\mathbf{)}$. A) Compound 1, B) Licofelone acyl glucuronide 


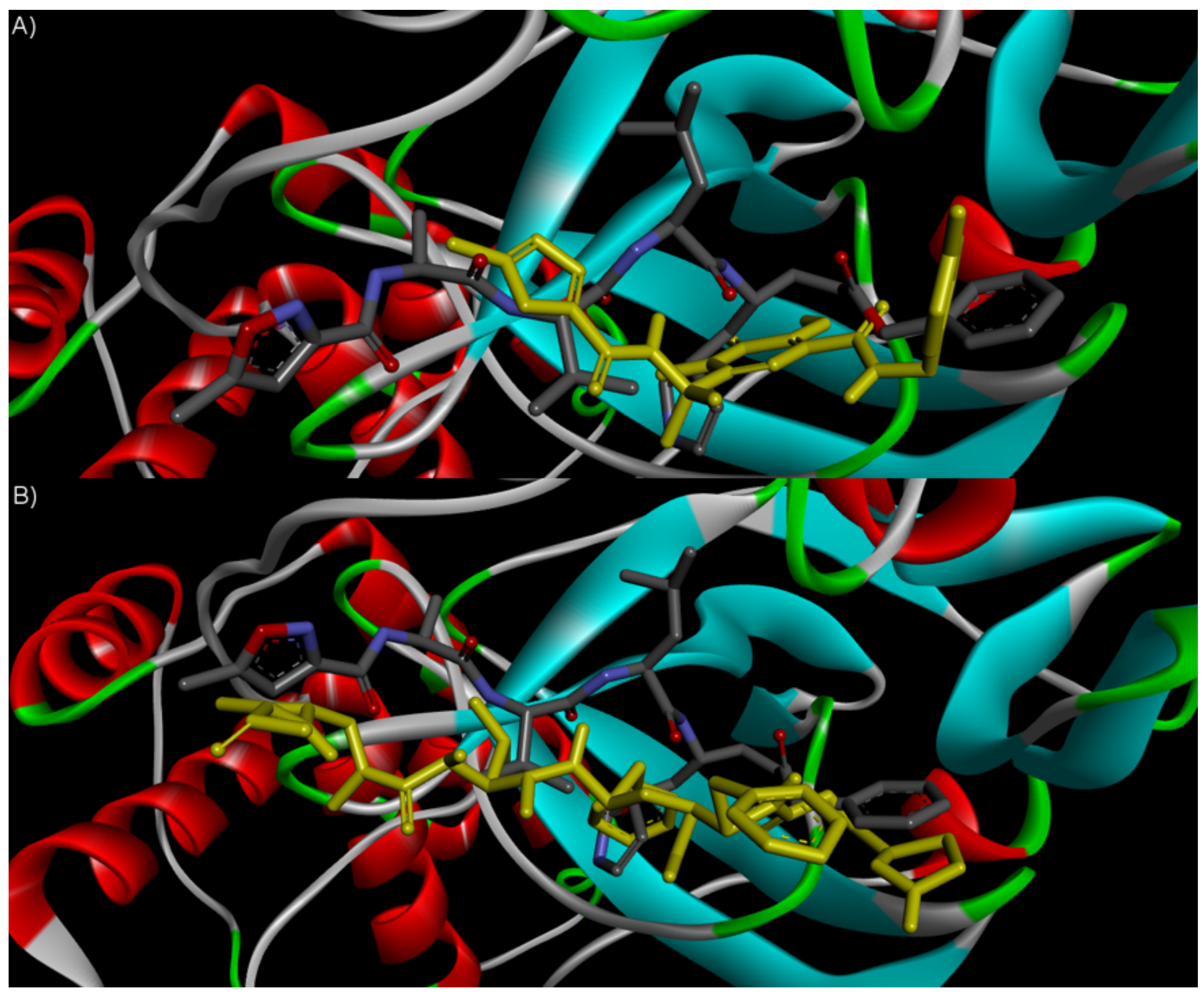

Figure 5

The overlap images of crystallographic binding mode of ligand N3 ( $)$ and predicted binding mode of potential inhibitors ( $(\mathbf{)}$. A) Raltegravir and B) Ritonavir. 
A)

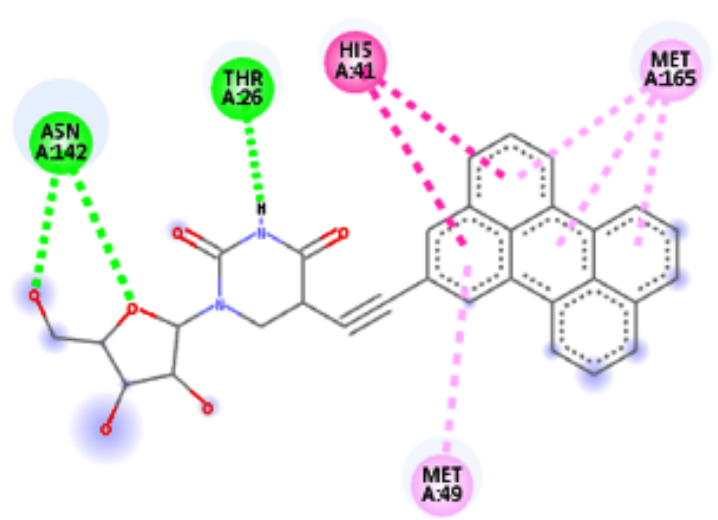

Interactions

$\square$ Conventional Hydrogen Bond

Pifi T-shaped

C)

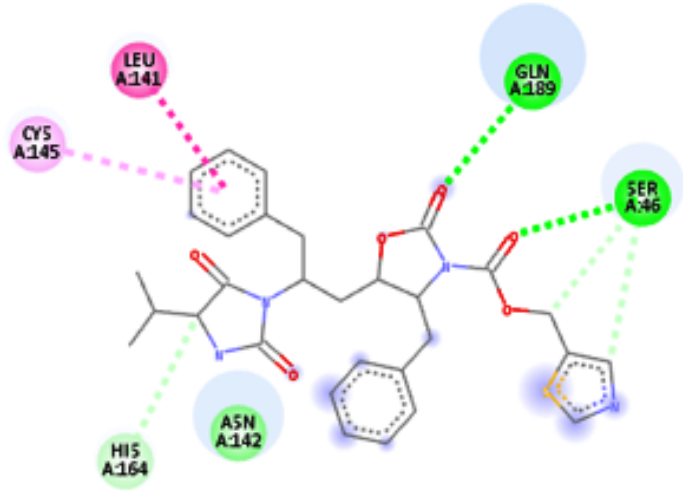

Interactions

$\square$ van der Wasts

Conventonal Hydrogen Bond

Carbon Hydrogen Bond
B)

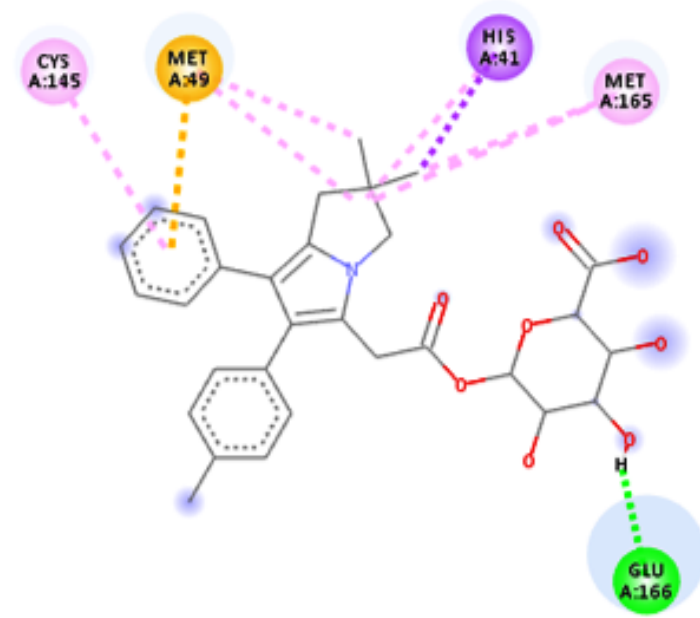

Interactions

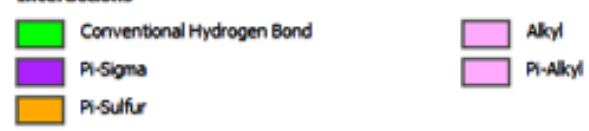

D)

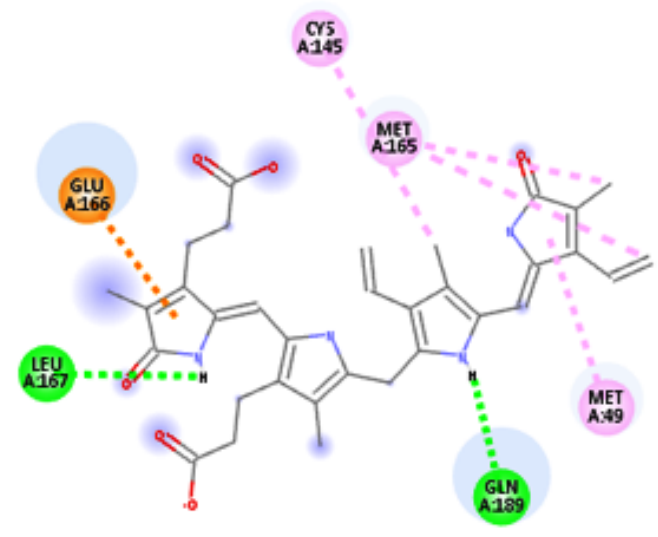

Interactions

$\square$ Conventional Hydrogen Bond
$\square$ Pr-Anion

\section{Figure 6}

Docking result analysis for synthetic inhibitors: The 2D image of A) Compound 1, (B) Licofelone acyl glucuronide, (C) Ritonavir impurity $\mathrm{H}[\mathrm{EP}]$ and (D) delta-Bilirubin. 


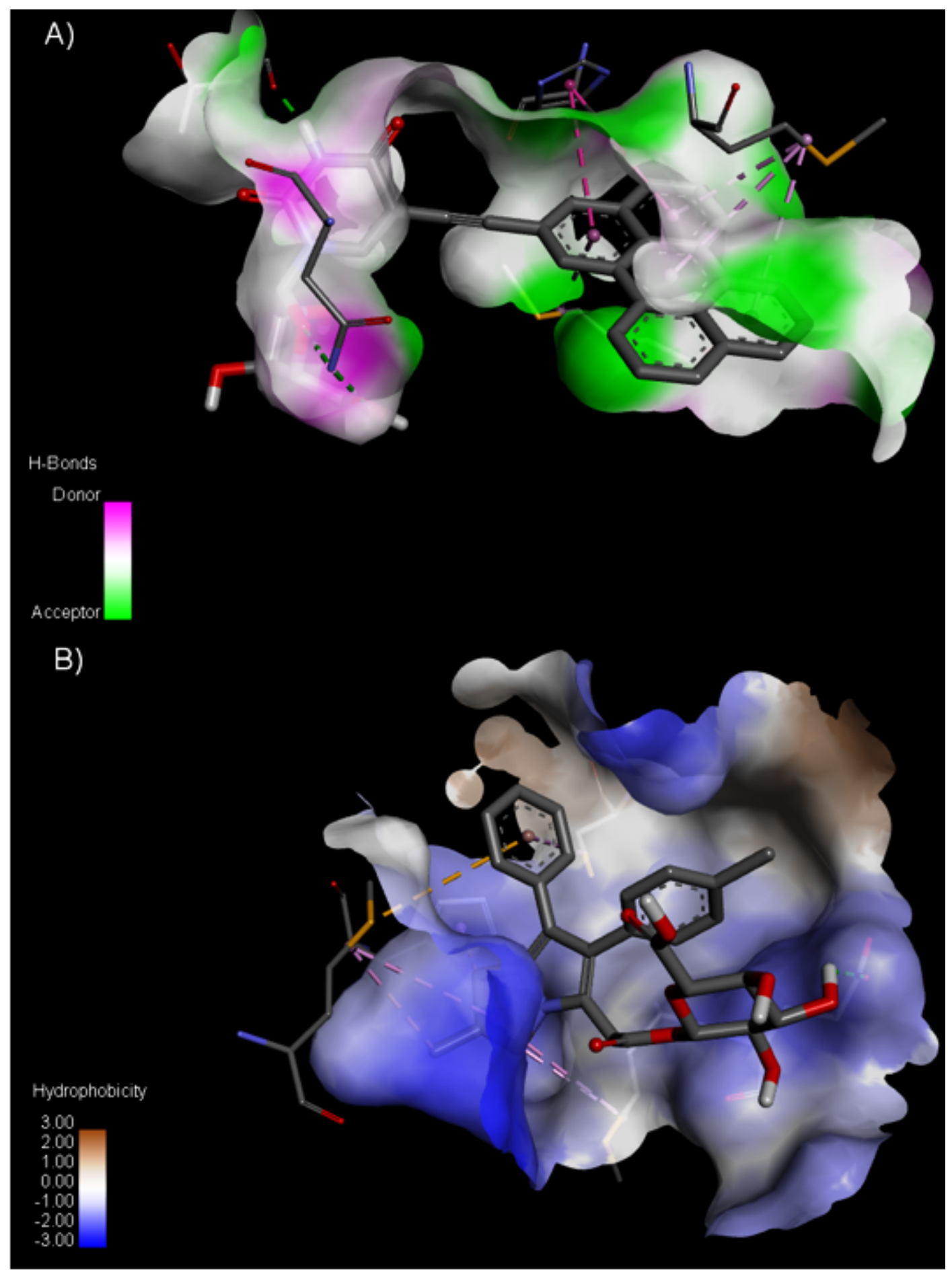

\section{Figure 7}

The 3D image of (A) the hydrophilic environment created by Compound1, and (B) the hydrophobic environment created by Licofelone acyl glucuronide. 


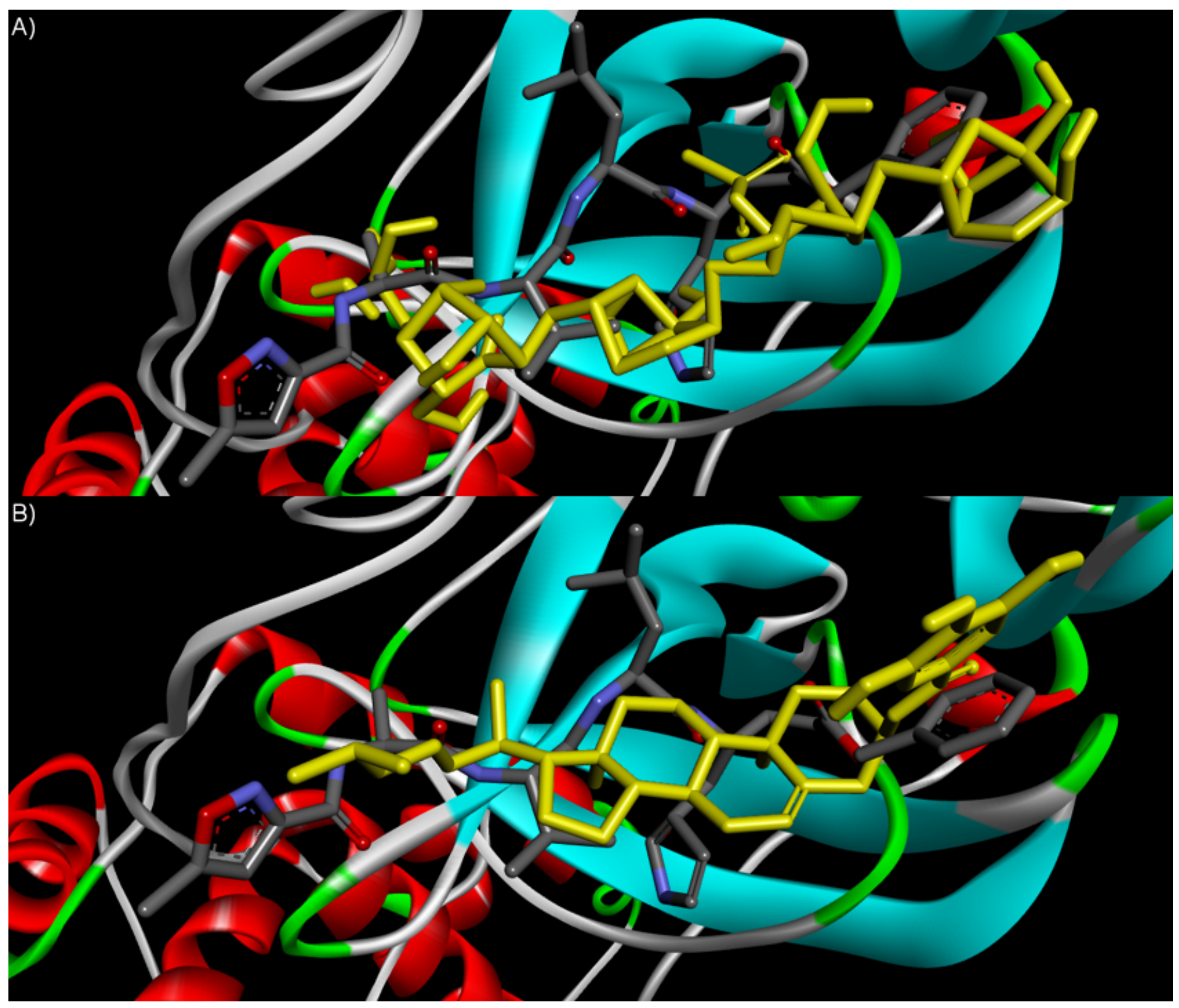

Figure 8

The overlap images of crystallographic binding mode of ligand N3 ( $)$ and predicted binding mode of potential inhibitors (). A) kappa-Carrageenan and B) Gallic acid 3-cholesteryl ester. 
A)

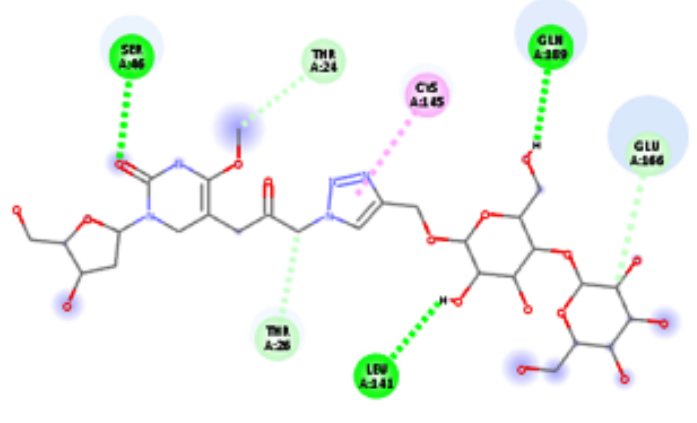

Interactions

Conventional Hydrogen Bond

Carbon Hydrogen Bond

C)

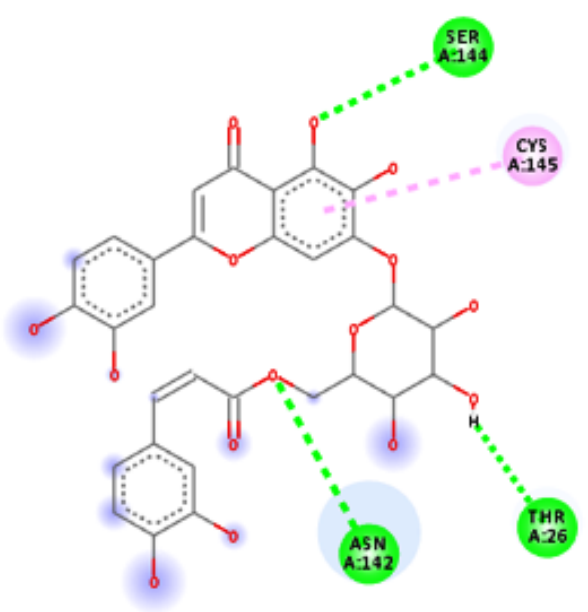

Interactions

$\square$ Conventional Hydrogen Bond
B)

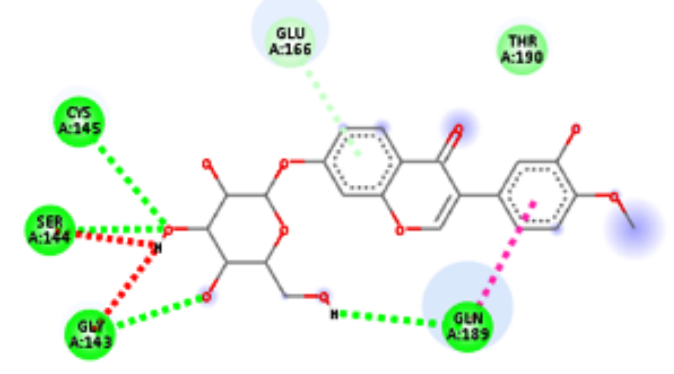

D)

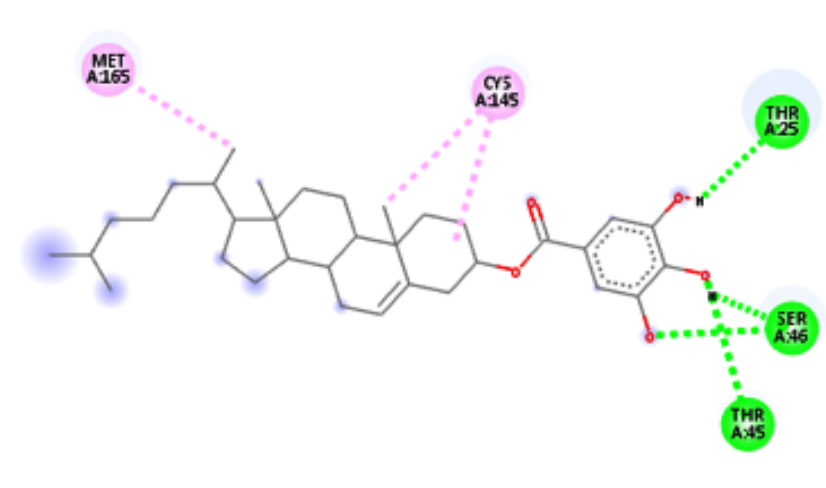

Interactions

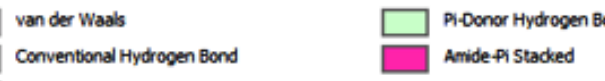

Unfavorable Donor-Donor

Conventional Hydrogen Bond

Akyl

\section{Figure 9}

Docking result analysis for natural inhibitors: 2D images of (A) beta-D-galactopyranosyl, (B) Calycosin 7O-glucoside, (C) Spicoside A, and (D) Gallic acid 3-cholesteryl ester. 
B)
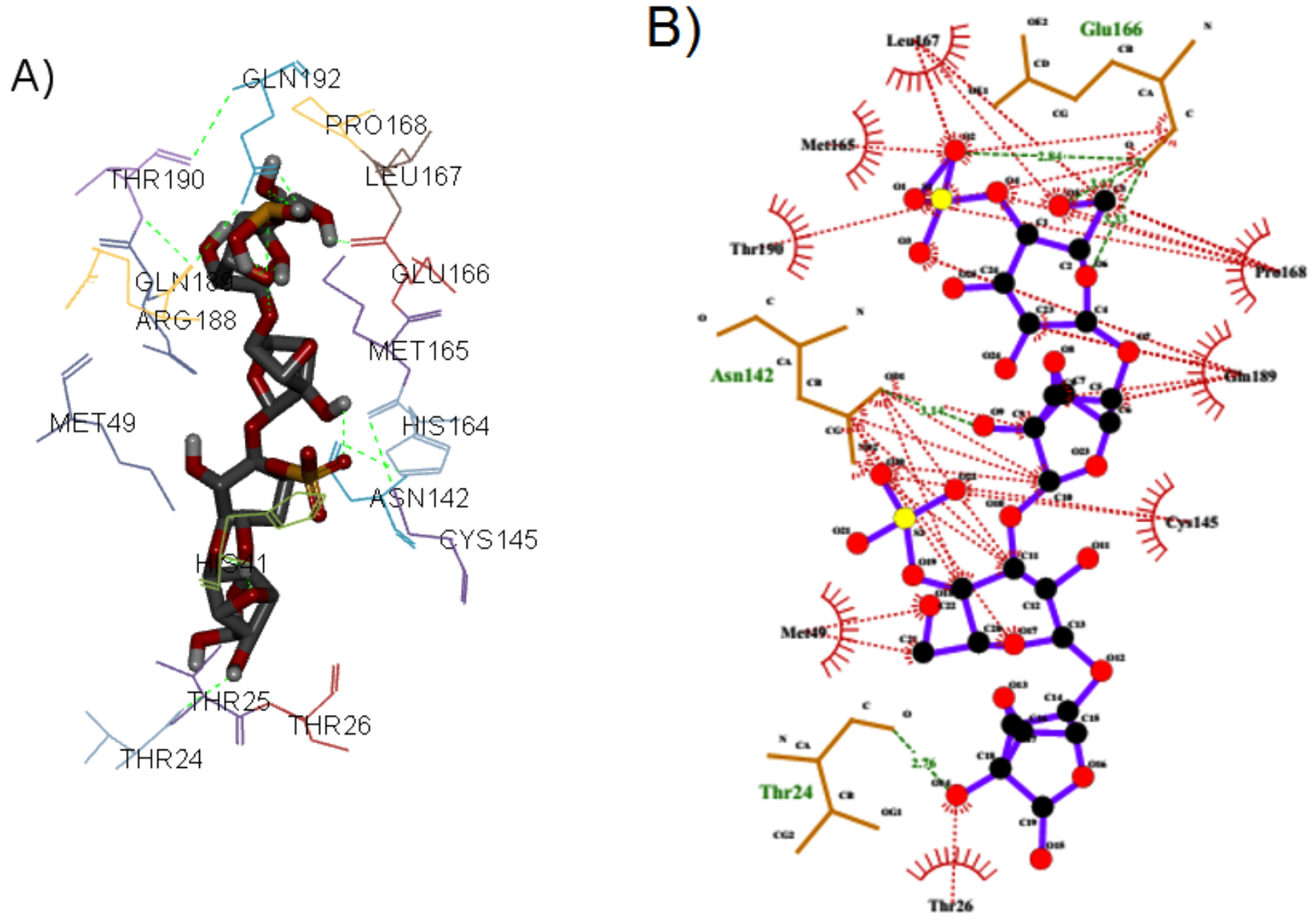

Figure 10

Kappa-Carrageenan conformer-receptor interactions: A) 3D and B) 2D images.

\section{Supplementary Files}

This is a list of supplementary files associated with this preprint. Click to download.

- SupportingInformation.docx

- GraphicalAbstract.tif 